\title{
A ARTE DA ESCUTA ${ }^{1}$
}

\author{
Lisabete Coradini \\ NAVIS/DAN/PPGAS UFRN
}

\begin{abstract}
Dedico este memorial a meu pai e minha mãe (in memoriam), por terem me ensinado o valor das pequenas histórias e como viver com dignidade.

De forma especial, para Sofia e Carlo, parceiros de muito amor e de partilhas ao longo da vida.
\end{abstract}

\section{COMO ALERTA PAULO FREIRE EM UMA CARTA DE 1986:}

Neste sentido, a luta pela Universidade de meu sonho, substantivamente democrática, deselitizada, séria, comprometida com a ciência sem ser cientificista, rigorosa, competente, crítica, exigente, criadora, avessa a qualquer forma de dicotomia: pesquisa, docência (produção do conhecimento, conhecimento do conhecimento existente); autoridade, liberdade; texto, contexto; ler, escrever; saber popular, saber acadêmico; teoria, prática; ensinar; aprender, a luta pela Universidade de meu sonho se dá politicamente na intimidade da Universidade real, concreta, em que me acho. A luta por ela se dá na luta política em favor da sociedade com que sonho, que não aparece por acaso, nem por decreto, nem por voluntarismo de nenhuma espécie, mas pela transformação da que ai está, concreta, real. Por isso é que a posição tradicionalista, cega e surda aos interesses de classe no espaço escolar e para a qual ensinar e aprender são atos puros e castos, em nada tem a ver com o meu sonho de Universidade.

\section{COMEÇANDO A ESCREVER}

Não é uma tarefa fácil escrever memorial, remete a uma história, refletir sobre 22 anos de Universidade, tentei fazer texto, nem tão formal e nem tão ensaístico. Tentei mostrar como eu fui levada a abordar certos temas e como fui afetada de corpo e alma por essas escolhas. Este memorial não é formado somente por palavras; existem também imagens, os afetos, as partilhas.

Gostaria de agradecer à banca formada pelos professores, Dr. Rogério Proença Leite (UFS), Dra. Veneza Mayora Ronsini (UFSM), Dra. Carmen Rial (UFSC) e Dr. Luiz Assunção (UFRN). Agradeço também a Maria Angela Pavan (UFRN), amiga, colega de trabalho e com quem eu tenho a honra de compartilhar nossos tempos, nossas histórias e nossas experiências. Aos colegas de Departamento de Antropologia e do PPGAS, alunos do Curso de Graduação em Ciências Sociais e do PPGAS, orientandos, ex-orientandos, futuros orientandos, bolsistas dos projetos de pesquisa e extensão, meus amigos, minha família de amigos. 
Antes de começar a escrever este memorial, pensei muito, li e reli vários trabalhos que realizei, dos quais alguns foram publicados e outros ainda estão na gaveta da escrivaninha. Essa situação de ter que escrever um memorial me levou a pensar na minha própria trajetória "individual". É uma reflexão sobre as inquietações que a Antropologia vem provocando em mim desde a graduação em Ciências Sociais, notadamente no que diz respeito à questão metodológica, um desafio colocado para o antropólogo que estuda a sua cidade. Minhas inquietudes hoje em dia permanecem, embora busque novos ângulos e novos horizontes.

Enquanto estudante do Curso de Ciências Sociais, para entender a minha própria cultura, foi importante a leitura do ensaio de Roberto da Matta (1978) intitulado Anthropological Blues, em que ele trata do duplo ofício do etnólogo, qual seja: transformar o exótico em familiar e o familiar em exótico. Foi através dessa leitura que percebi estarmos o tempo todo pressupondo familiaridades e estranhamentos. Eu li esse texto na Graduação como sugestão de meu orientador para auxiliar na pesquisa de campo, já que se tratava de um lugar aparentemente bastante familar. Trata-se de um trabalho monográfico intitulado "Desvio na praça", sobre a Praça da Alfândega em Porto Alegre, RS. $\mathrm{O}$ encontro com o antropólogo e professor Jorge Bozzobon foi fundamental para seguir a minha carreira acadêmica, os ensinamentos aprendidos naquelas longas conversas, nas orientações e nas leituras sugeridas. Esses ensinamentos impregnaram-me e lançaram-me a outros tantos voos e nortearam os meus caminhos e a minha vida. Obrigado, Jorge. Salve, Jorge!

Visitar o passado nos leva a refletir sobre a memória, como disse Mia Couto: "revisito esse momento como a primeira pedra deste texto. [...] esta persistente lembrança, que saboreio como uma sombra eterna é quase uma metáfora do trabalho da memória, um fio tênue, juntando-se a outros fios que se enroscam num redondo ventre" (COUTO, 2011, p. 189).

Mas a palavra memória, como diz o historiador Peter Burke, é mais sobre o que esquecemos do que sobre o que lembramos. É profundamente necessário esquecer para poder lembrar. Da mesma maneira, comunicar pressupõe não só a fala, mas também a escuta. Todos nós, segundo a mitologia grega, bebemos um gole de água do rio Letes, o rio do esquecimento, que apaga algumas lembranças. É sempre um desafio para quem trabalha com memória e lembrança, pois ela está sempre se renovando com os novos acontecimentos. Quem nos traz uma reflexão rica sobre esse assunto é a pesquisadora argentina Beatriz Sarlo (2007), alertando-nos de que a memória sempre é um campo de batalhas, por haver sempre a palavra esquecimento como companheira desse processo. E acrescenta: "não há testemunho sem experiência, mas tampouco há experiência sem narração: a linguagem liberta o aspecto mudo da experiência, redime-a de seu imediatismo ou de seu esquecimento e a transforma no comunicável, isto é, no comum" (SARLO, 2007, p. 24).

O escritor Borges nos trouxe para pensar o conto "Funes el memorioso" onde o esquecimento seria uma necessidade humana para o percurso da vida. $\mathrm{O}$ personagem Irineu Funes, cai e no tombo contrai a doença da incapacidade de esquecer. Um conto de ficção que nos faz refletir o quanto o esquecimento faz parte da própria vida. Afinal, a memória se faz por lembranças e esquecimentos.

A memória se constitui também por lugares, eventos, registros, arquivos, passagens, e está em constante transformação. Dessa forma, ao narrar a minha trajetória intelectual e acadêmica, descarto a possibilidade de tratá-la como algo coerente e finalizada. 
A partir dessas perspectivas, este texto tomará a forma de uma narrativa autobiográfica. Tarefa extremamente difícil e complexa. Narrar a própria vida buscando as interconexões entre o oral, o visual e a escrita, remetendo a experiência da alteridade, das descobertas etnográficas e dos deslocamentos. Descrever uma trajetória profissional a partir de diversas narrativas - publicações, produções audiovisuais, artigos, pesquisa de campo, orientação, participação em bancas e eventos ${ }^{2}$.

Sendo assim, regresso ao novelo da lã mencionado através das belas palavras de Mia Couto e passo a narrar esse memorial como sujeito histórico inserido em processos acadêmicos, pois dela fazem parte meus filhos, meus pais, meus alunos, meus colegas, meus orientandos e as relações mantidas com outros contextos ou conjunturas. São encontros, trocas, conversas, confissões, recheadas de cheiros, gestos, cores, sons, que compõem um cenário, uma atmosfera envolvente, que nos move e nos mantém vivos. Revisitar esses e outros momentos de partilha de entendimentos não foi tarefa nada fácil.

A possibilidade de lembrar e rememorar me leva a reconhecer um conjunto de conquistas, o título de mestre, título de doutor, o pós-doutorado, tudo isso é necessário. Mas, para mim, há outra coisa importante e tem um nome: ética. Sem ética não seremos nem professores nem pesquisadores. Ética, para $\mathrm{mim}$, significa um ato de entrega. Significa "viver com verdade", com assinala Eliane Brun (2013).

Aprendi a "viver com verdade" com meus pais, senhor Nelsis Coradini e Dona Geni Maria Biacchi Coradini. Com eles, aprendi a prestar atenção nas pequenas histórias e viver com dignidade e com verdade.

Meus pais, netos de imigrantes italianos, moravam nas matas fechadas no interior do Rio Grande do Sul. Meus bisavós, como a grande maioria dos imigrantes, eram camponeses vindos do Norte da Itália, que se tornavam pequenos "colonos" no Brasil. Minha família, os Coradini-Biacchi, é originária da região do Vêneto. Vale ressaltar que os italianos foram atraídos para o Sul do Brasil com o intuito de substituir a colonização alemã, quando a Alemanha passou a criar mecanismos para impedir a imigração para o Brasil, devido às denúncias contra essa imigração, tendo em vista que muitos passavam privações no país. Estima-se que do total de imigrantes que veio para o estado, $54 \%$ era de vênetos, $33 \%$ de lombardos, $7 \%$ de trentinos, $4,5 \%$ de friulanos e as outras regiões forneceram os restantes 1,5\%. Calcula-se que, entre 1875 e 1914, entraram no estado entre 80 e 100 mil italianos. Minha família Coradini -Biacchi são originários da região do Veneto.

Com minha mãe, aquariana, aprendi a prestar atenção nos gestos, nos olhares, nos lugares e nos saberes locais. Minha mãe gostava de cozinhar e reunir a família em torno de uma mesa farta com comidas caseiras, adorava jogar bocha, pescar na beira de rio e apostar na Mega Sena. Possuidora de habilidades manuais invejáveis era uma exímia artesã, tímida, encantava a todos com sua generosidade. Ela foi uma mulher que atuou em várias frentes, e eu desde pequena tornei-me também a sua mais assídua companheira. Aprendi o significado da palavra cumplicidade.

Alguns anos mais tarde, no mestrado, através da leitura do ensaio sobre a dádiva, do antropólogo Marcel Mauss, pude entender melhor o significado de doar e receber. Falo do "Ensaio sobre a Dom", de 1924, que foi considerado um dos dez textos mais importantes da não-ficção no século 20 por júri do caderno Mais, publicado em 11/04/1999.

Doar e receber são dois verbos necessários na vida. Quando alguém nos cuida, cuidar em dobro é devolução de vida. A necessidade de retribuir as 
dádivas e a obrigatoriedade da troca representa o desejo da relação social pura e se manifesta na linha sutil que nos une e nos deixa fortes. Falo da troca não-mercantil, mas a troca de vida. Dessa troca de que trata Marcel Mauss, meu antropólogo preferido, que tinha 46 anos quando publicou o já mencionado "Ensaio sobre o Dom: forma e razão da troca nas sociedades arcaicas", um belo texto sobre o espírito do doador, o direito, as obrigações e os compromissos de dar, receber e retribuir. Ele analisou as relações de troca (dom ou dádiva) entre os membros de uma determinada sociedade, na Melanésia, na Polinésia e no Nordeste dos EUA. Com Mauss, aprendi que antes da troca existe o dom, ou seja, ao receber um presente o donatário deve retribuir com outro dom, que é diferente de devolver o presente recebido. Minha mãe trouxe para minha vida esse dom que acende o fio sutil que nos une. As trocas da sociabilidade e intercâmbios é que nos mantêm vivos e com a certeza de que a vida sempre está carregada de dádivas.

Meu pai, homem austero e batalhador, foi um visionário para sua época. Casou-se muito jovem, com 20 anos, minha mãe com 18 anos. Desde jovem enfrentou as lidas no campo, trabalhou na roça, plantando milho e arroz, e também cortando madeira. Uma atividade braçal típica dos migrantes italianos da região de Santa Maria-RS. Depois do casamento, que se realizou debaixo de muita chuva, a maior enchente que havia acontecido naquele lugar, eles foram se estabelecer em Caçapava do Sul. Nessa cidade, eu e meu irmão nascemos. Meu pai trabalhou como garçom e aos poucos foi se tornando um comerciante. Naquela época, eu saía do colégio e ia direto para trás do balcão. Adorava atender, empacotar presentes e ouvir os "vinis" que ali chegavam. Como também "roubar" a bicicleta mais incrementada da época. Pedalar ainda é uma das minhas grandes paixões, além da natação, por isso sempre morei perto do mar.

Meu irmão, Luis Alberto, lembra com carinho como ele aprendeu o ofício de ser empresário. Ele e meu pai, nos finais de semana, depois de uma semana intensa jornada de trabalho, percorriam o interior do município, com caminhão, para levar as últimas novidades do mundo moderno: geladeiras, máquina de costura, fogão, e demais modernidades. Alguns anos depois, já doente, meu pai contava como "ganhou" a vida, não esquecia um detalhe, eram histórias tão reais que pareciam inventadas. Meu pai foi um visionário, um sonhador e, sobretudo, um homem perspicaz e inteligente.

Com ele aprendi a ouvir e captar o tom dos sons das palavras. Percebi que as palavras produzem sentidos e atentei ao poder que elas têm em criar realidades. A Antropologia veio confirmar aquilo em que eu acreditava. Eu sempre achei que ouvir era mais importante do que saber perguntar. A Antropologia fez-me exercer com esmero o ofício de captar o tom e o ritmo das palavras. Eu acredito na "vida contada". Tudo que eu aprendi na minha vida foi através da minha vivência e do que li nos livros.

\section{GRADUAÇÃO}

Como havia dito, nasci numa pequena cidade do interior do Rio Grande do Sul, Caçapava do Sul, que, na língua Tupi Guarani, significa "Clareira na Mata". Surgiu de um acampamento militar localizado no antigo povoamento dos índios charruas. Apesar da forte influência indígena e negra, durante muitos anos essas heranças culturais foram relegadas ao silêncio e esquecimento. Uma cidade dividida, com uma forte segregação espacial e racial: clube social para brancos, clube social para negros, CTG de brancos, CTG de negros. Eu lembro que apenas os clubes de futebol admitiam negros, como o famoso jogador Caçapava, da equipe do Clube Caçapava. Vale lembrar que ao longo dos 
anos esses CTG (Centro de Tradição Gaúchas) se transformaram em lugares de reafirmação indenitária negra, com a finalidade de agregar negros e pobres, principalmente os domiciliados no interior do município que não tinham condições de socializarem-se nas demais entidades tradicionalistas. Esses CTG passaram a ser referência para comunidade negra de Caçapava.

A casa dos meus pais era bem localizada, área central da cidade, na Rua 15 de novembro, 183. Eu tive o privilégio de ter como vizinho o seu Nicolau (Nicolau da Silveira Abrão), que escreveu o livro "História do Município de Caçapava do Sul" e, também, de "seu Antônio", o fotógrafo. Passei os dias da minha infância e adolescência ouvindo os causos do seu Nicolau, que na sua narrativa incorporava aspectos da memória da cidade e do seu Antônio, o fotógrafo, que me ensinou os primeiros passos na arte de fazer fotografia $3 \times 4$.

Aos 16 anos, prestei o vestibular para Administração de Empresa na UFSM. Durante o curso, a disciplina que mais me instigava era pesquisa mercadológica. Li muitos livros sobre o tema e participei como auxiliar de pesquisa, aplicando questionários de pesquisa de opinião e pesquisa sobre eleições municipais em um instituto de pesquisa na cidade.

Após a conclusão do curso de administração de empresas, fui para a capital do estado do Rio Grande do Sul, Porto Alegre, continuar meus estudos em Comércio Exterior, na UNISINOS. Comecei a cursar algumas disciplinas de métodos e técnicas de pesquisa no curso de Ciências Sociais. Aos poucos, fui entrando em contato com a Sociologia e a Antropologia. Não demorou um semestre, desisti de Comércio Exterior e fui fazer Ciências Sociais. Sempre me interessei pelos métodos de pesquisa, talvez tenha sido essa a razão de ter abandonado a carreira de administradora de empresas para ser cientista social. O método me fascinava.

Durante a Graduação em ciências sociais, apenas duas disciplinas de antropologia eram obrigatórias, o curso tinha um viés marxista e oferecia um número maior de disciplinas advindas de Ciência Política e Sociologia. Esse conjunto de disciplinas permitiram conhecer as obras clássicas - Marx, Engels, Weber - como também "Sobrados e mocambos", de Gilberto Freyre; "Raízes do Brasil", de Sérgio Buarque de Holanda; "A construção da ordem", de José Murilo de Carvalho; "O quinto século", de Maria Alice Rezende de Carvalho e "Tradição e artifício", de Rubem Barbosa Filho. Além de autores que serviram de inspiração, como Florestan Fernandes, Otavio Ianni, José Murilo, Darcy Ribeiro e Wanderley Guilherme. Por outro lado, a obrigatoriedade da história, a teoria literária e a filosofia política, entre outras disciplinas, contribuíram para um alargamento do meu entendimento sobre o pensamento social brasileiro.

Mas não só as duas disciplinas em Antropologia foram importantes para minha formação. Lembro-me do seminário que tive que apresentar, em cultura brasileira, uma leitura crítica do livro Antropologia Cultural de Luiz Gonzaga de Mello, um desafio ler muitas páginas, resumir e apresentar em sala de aula. Mas foi um mergulho sem respirar na Antropologia, pois se tratava de um estudo que apresenta alguns dos principais temas da antropologia social: família, parentesco, instituições, modos de subsistência etc. E assim comecei a descobrir o infinito universo da Antropologia.

No meu deslocamento diário do trabalho para a universidade, conheci aquele que seria o meu futuro orientador, sentei ao lodo dele no ônibus, e ele me perguntou: "Você já leu 'Viva o povo brasileiro', de João Ubaldo Ribeiro?". Um romance, lançado em 1984, que mistura fatos reais com as fantasias ficcionais para retratar quatro séculos da História do Brasil. Paixão à primeira vista. Isso 
foi o suficiente para começar uma orientação que só foi interrompida com a sua morte.

Jorge Bozzobon entregou-me uma folha com anotação de todos os autores que eu deveria ler, título da obra, páginas, principais conceitos. Como cancerina, apegada ao passado e aos papéis e blocos de anotações, guardo até hoje essa "relíquia" com os nomes daqueles que iluminaram o meu caminho: Durkheim, Mauss, Van Gennep, Hall, Foucault, Turner. E também a sugestão de um livro importante para o trabalho de campo "A Aventura Sociológica". Após nossa reunião de orientação, fui para o centro de Porto Alegre-RS, sentei no banco da praça e comecei a observar e escutar o que as pessoas tinham a dizer. Esse trabalho de campo resultou na minha monografia intitulada desvio na praça.

Aliás, o meu primeiro desafio, durante o trabalho de campo, foi o da distância e proximidade do investigador com relação ao seu objeto. Tarefa nada trivial e nem sempre bem-sucedida, como alertam alguns antropólogos. Transitar por caminhos tão próximos sem enxergar as diferenças tão próximas.

Esse olhar sobre o diferente me fez perceber a dificuldade de desnaturalizar noções, categorias, classificações que constituem minha visão de mundo. Como nos ensina o antropólogo Gilberto Velho (1994), a possibilidade de nosso empreendimento ser bem-sucedido vai depender das peculiaridades da própria trajetória dos pesquisadores, que poderão estar mais inclinados ou aptos a trabalhar com maior ou menor grau de proximidade com seu objeto.

\section{PÓS-GRADUAÇÃO EM ANTROPOLOGIA}

No final dos anos 80 , dando continuidade à minha monografia, prestei concurso para o PPGAS na UFSC, com um projeto sobre sociabilidade e espaço público, cujo objetivo inicial era mapear os grupos que se apropriavam da área central em Florianópolis, Santa Catarina. A dissertação foi publicada em formato de livro com o título "Praça XV: espaço e sociabilidade".

Nessa dissertação de mestrado sobre a Praça XV de Novembro, em Florianópolis, como dito, o objetivo inicial era mapear os diferentes usos e apropriações do espaço público. E para tanto, entrevistei diferentes frequentadores, assíduos e eventuais, buscando identificar os diversos usos e significados dado ao espaço e compreender as redes de sociabilidade construídas pelos meus interlocutores. Além disso, acompanhei os eventos, em especial, carnaval, as procissões e as festas cívicas. Como a temática envolvia aspectos da construção do imaginário social da cidade, utilizei como fonte de pesquisa as crônicas sociais e policiais, revistas e jornais locais. Nesse trabalho, foi preciso exercer o distanciamento, para ter uma visão de conjunto e encontrar um fio condutor no uso das múltiplas fontes. Mas foi ao mergulhar naquele universo que compreendi a importância da Etnografia e da relação dialógica do eu/outro. O esforço de compreender o horizonte cultural do outro estimula a compreensão da minha cultura, ao mesmo tempo que consiste num esforço de compreensão do próprio horizonte do pesquisador. ${ }^{3}$

Durante o mestrado, tive a oportunidade de ter como professores Silvio Coelho dos Santos, Rafael Bastos, Miriam Grossi, Carmen Rial, Ilka Boaventura Leite e Jean Esther Lagdon. Em 1994, conclui o Mestrado em Antropologia na PPGAS da UFSC, sob a orientação da professora Ilka Boaventura Leite. Meu olhar sobre as identidades étnicas urbanas foi aguçado através de diferentes projetos $^{4}$. Projetos esses de que participei como pesquisadora e uma das funda- 
doras do Núcleo de Estudos sobre Identidade e Relações Interétnicas (NUER). Durante os anos 1992, 1993 e 1994, participei de projetos sobre identidade e territorialidade. Além da realização e produção de um vídeo documentário sobre mercado público de Florianópolis (NUER, 1994, 20 min).

\section{DOUTORADO}

O ano de 1994 foi muito emblemático. Realizei o sonho de aprovação num concurso público para professor de Antropologia em uma Universidade Pública. Tomei posse na Universidade Federal do Rio Grande do Norte e, no mesmo ano, o meu projeto de doutorado no instituto de Investigaciones Antropológicas (IIA) da Universidad Autonoma de México (UNAM) foi aprovado pela CAPES. Conseguir adiar meu afastamento para o ano de $1996 \mathrm{com}$ apoio dos meus colegas de Departamento. De 1996 a 1999 realizei doutorado no IIA, na UNAM.

Na minha tese, propus-me a analisar as memórias do futuro, ou seja, a maneira como nossas cidades - as cidades do fim do século XX - foram imaginadas pelo cinema, pela literatura, pelas séries de televisão e pela arquitetura. $O$ trabalho trata de mostrar as diferentes facetas do imaginário futurista da cidade e comparar com os projetos urbanísticos utópicos elaborados nas décadas de 50 e 60. Também tenta mostrar por que o movimento moderno em arquitetura foi considerado um estilo para construir utopias sociais, através de duas propostas de utopias urbanas construídas sob a influência do movimento moderno: a construção de Brasília e a construção de Ciudad Satélite, no México.

Ao analisar os textos visuais (literatura, periódicos, revistas) e textos audiovisuais (filmes e vídeos) com o objetivo de descrever as imagens que os mesmos textos construíram sobre o futuro, percebi que se tratava de diferentes imagens que refletem as facetas distintas do imaginário. Partindo da relação entre imaginário e os meios visuais e audiovisuais em torno do futuro, explora-se as possibilidades de ler a cidade como um espaço de polifonia.

A pesquisa na qual se baseia a tese foi feita entre 1998 e 2000 e apoia-se numa combinação de métodos e tipos de informação. Nesse sentido, a investigação encontra-se dimensionada por incontáveis trabalhos e estudos desenvolvidos por antropólogos, historiadores, arquitetos, cineastas, escritores e traduzem na articulação destas referências teórico-conceituais na análise das cidades americanas. Discutem-se os conceitos de modernidade e imaginário, relacionados com a análise das cidades latino-americanas. A opção de privilegiar as cidades americanas tem uma razão simples: as cidades europeias passavam na década de 50 por uma fase de recuperação, saindo como estavam de duas guerras mundiais, enquanto as cidades americanas passavam por uma fase distinta e pensavam o futuro de forma diferente.

Para esse entendimento, recuperei a história da urbanização em México D.F. e Brasília; usei os jornais como fonte empírica de coletas de dados principalmente de 1945 a 1960; realizei um levantamento e pesquisa em revistas de arquitetura; utilizei entrevistas com diferentes interlocutores (cineastas, arquitetos e historiadores), permitindo preencher as lacunas da documentação impressa. Recorri também ao registro fotográfico.

Pensar as cidades significa refletir sobre as metáforas que povoam os imaginários construídos sobre elas, enfrentar a memória e a história processadas nos projetos urbanos. Nesse sentido, analisei as diferentes imagens que refletem 
diferentes facetas do imaginário futuristas da cidade e aproximá-las dos projetos urbanísticos utópicos elaborados nas décadas de 50 e 60 no Brasil e no México.

Nas Ciências Sociais, a cidade ocidental moderna tem sido alvo de diferentes matrizes teóricas, já tendo sido tratada de forma mais abstrata e generalizante pelos clássicos: Max, Durkheim e Weber. Este último tratou de definir seu conceito de cidade baseando-se nas origens da Civilização Ocidental. Marx, por sua vez, define esse território como o lugar instável e de conflito, onde nasce um novo ator político: o proletariado, e consequentemente os conceitos como "alienação urbana", "proletariado industrial".

Na década dos anos vinte do século passado, floresceu um movimento criado por alguns teóricos preocupados em estudar o crescimento das cidades. Esses estudos ficaram conhecidos como "Escola de Chicago", cujos representantes transformaram a cidade num laboratório social - com o interesse de buscar soluções para a cidade marcada pelo crescimento populacional, pelo intenso contingente migratório e pela segregação urbana. Seus principais expoentes foram Park, Simmel, Wirth e Redfield. "A cidade: sugestões para a investigação do comportamento humano no meio urbano" de Park, publicado em 1916, que completou cem anos. Por sua vez, Louis Wirth, utilizou modelos urbanos com ênfase em grupos secundários, segmentação de papéis e aumento da mobilidade social. Simmel que publica "Urbanismo como modo de vida" (1938) e busca elaborar em seus estudos uma teoria do indivíduo e da metrópole, questionando a emancipação daquele e a forma como esta intervém nesse processo.

Desde os anos 50 até o início dos anos 60, a cidade foi explorada por estudiosos, como Castells, Lojkine, Lefebvre que politizam a questão urbana, descrevem os movimentos sociais, o cotidiano nos países da América Latina. Dos estudos urbanos no Brasil, destacam-se as pesquisas pioneiras de Francisco Oliveira, Maria Célia Paoli, Lúcio Kowarick e Lúcia Valladares. E os estudos de comunidades inspirados pelos antropólogos americanos Donald Pierson, Charles Wagley e Antônio Cândido. No final dos anos 70, os estudos de Antropologia privilegiaram o trabalho de campo, com interesse especial índios, negros, favelados, pobres, em detrimento do estudo de grupos ou classe politicamente dominante, os estudos de Eunice Durham, Ruth Cardoso, Gilberto Velho, Roberto da Matta, Alba Zaluar, Ruben Oliven, entre outros.

Nos anos 80, autores destacados, como Foucault, Mafessoli, Guatarri, Marc Augé, Michel Argie, Edgar Morin, Michel de Certeau apontam em suas obras leituras inovadoras que tratam de questões da metrópole e de como esta se converte num espaço da modernidade ou da pós-modernidade. No início dos anos 90, novos conceitos urbanos aparecem como "imaginários urbanos", de Armando Silva (1992); "consumo cultural", de Garcia Canclini (1995); "identidades emergentes", de Urtega (1995); "cidade polifônica", de Canevacci (1993); "a cidade modernista", de Holston (1993); "as cidades do amanhã", de Hall (1995); "as cidades invisíveis", de Ítalo Calvino (2000); "comunidade interpretativa" de Paul Rabinow (1999); "pedaço" de J.G. Magnani (1992): "relatos e narrativas" de Cornélia Eckert e Ana Rocha (1997). Todos esses conceitos revelam uma diversidade de pontos de vista - desde os discursos normativos, aos interstícios, à desordem, à ilegalidade, à apropriação do espaço, ao cotidiano -, sendo, enfim, conceitos que alimentam e retroalimentam novas pesquisas no meio urbano.

É interessante pensar que, hoje em dia, nossas discussões versam sobre a realidade virtual, inteligência artificial, fake news, entre outros temas. Segundo alguns estudiosos, estamos passando por uma revolução tecnocientífica sem precedentes para a humanidade (Haraway, Fiting, Virílio). E nossa visão de mundo tem sido remodelada em função da velocidade com que as teorias se põem em 
prática. As concepções acerca da cidade também passam a sentir esses efeitos e, à medida que passam as décadas, determinados aspectos se fundem para formar outros pontos de vista que recontextualizam a cidade, embora nenhuma dessas concepções destrua a outra, somente a ressignificam. Será?

Essas questões sempre me acompanharam e me motivaram a pensar sobre as cidades. No meu doutoramento me propor a realizar uma investigação sobre o futuro das cidades. Lendo e relendo alguns autores, descobrindo outros, uma surpresa conhecer a contribuição do pensamento de Edgar Morin, que foi importante para entender noção de futuro, incerteza, complexidade. Sob a orientação de dois tutores: Rafael Perez Taylor (IIA/UNAM) e Cesar Gonzáles (IIF/UNAM).

Meu primeiro contato com o México foi através da literatura; o novelista brasileiro Érico Veríssimo, que havia visitado o México nos anos 50, publicou uma crônica dessa viagem cujo título é precisamente México: História de uma Viagem. Disse ele em determinado trecho, referindo-se à Cidade do México:

Por que terá esta cidade uma tão grande personalidade? O que é que a torna diferente das demais? De onde vira a aura de drama que a envolve? Creio que são vários os fatores e muitas as tintas que, combinadas, produzem, apesar de tanto sol, esse tom escuro e sombrio que nos dá a sensação de que a qualquer momento poderá ocorrer algo trágico, um assassinato, um terremoto, uma revolução... Não devemos esquecer, em primeiro lugar, que esta metrópole foi erguida sobre o cadáver de Tenochtitlan, assassinado por Cortés e seus soldados. Inclino-me a aceitar, com alguma fantasia, que uma cidade possa permanecer assombrada por um sentimento de culpa (VERÍSSIMO, 1964, p. 33).

Para conhecer melhor a cidade, recorri aos mapas, mas também caminhei pelas suas avenidas, por suas ruas, para localizar seus pontos de referência. A cidade está dividida, aparentemente bem planejada, quadriculada, compartimentalizada, como diria Foucault. Em fins dos anos 70, foram construídos 25 eixos que a cruzam tanto no sentido leste oeste como de norte a sul, numerados do centro até a periferia. A cidade possui um limite exterior, o anel viário periférico, e outro interior, o circuito interno, que rodeia os quatro pontos centrais do Distrito Federal; ambos os anéis viários foram construídos nos últimos trinta anos. Pergunto-me como foi possível construir uma estrutura de trânsito dessa natureza, se foi necessário desalojar pessoas e destruir suas casas. Pergunto-me como foi possível construir uma estrutura viária dessa natureza. A cada momento alternam-se sentimentos confusos como sedução ou medo, desprezo ou encanto.

Caminhando pelas ruas podemos sentir o cheiro e a cor da cidade: as ruas com seu comércio ambulante, com suas frituras e guloseimas como tortilhas e refrescos, os postos de gasolina com suas placas avisando perigo, os jardins perfumados e coloridos. No Centro podemos admirar prédios com influência da arquitetura clássica francesa, art noveau, vestígios das civilizações azteca e espanhola, edifícios de tezontle, pedra vulcânica, e granito cor purpura.

A Cidade do México apresenta características peculiares com relação a seu crescimento populacional. Em fins dos anos $60 \mathrm{e}$, principalmente, nos anos 70 , a cidade alcança altas taxas de crescimento em consequência da forte migração da população rural e de cidades de porte médio. A cidade começa a urbanizar-se. Era necessário construir moradias para abrigar tanta gente. Esse processo, havia sido iniciado nos anos 30 e 40, com a criação de colônias proletárias na periferia. Mais tarde, nos anos 60, iniciam-se os loteamentos da classe média sobre a zona noroeste da Cidade do México (cidade satélite) e, 
simultaneamente, as colônias populares no Noroeste (cidade Nezahualcóyotl) e resto da periferia. As modalidades predominantes de moradias na Cidade do México são: moradia unifamiliar, moradia agrupada horizontalmente, edifícios de apartamentos construídos verticalmente e conjunto habitacional

As medidas de organização e ordenamento chegam tarde e quando entram em operação já são obsoletas. O centralismo político a converte em área de maior atração, mas ao mesmo tempo o país se moderniza e o espírito de modernização transforma a plástica urbana da capital, segundo os mesmos padrões de todas as cidades do mundo moderno. "Somos fatalmente modernos", dizia Octavio Paz em uma entrevista.

As perspectivas de um futuro melhor ainda continuam provocando a imaginação de muitos arquitetos, escritores, intelectuais, planejadores urbanos, historiadores, cineastas. As distintas possibilidades nos planos tecnológico, econômico, social e urbanístico oferecem uma série de reflexões sobre a história da cidade e sua vida futura. São diferentes visões, diferentes perspectivas que provocam novas questões e novos temas.

A Cidade do México é um território polifônico, reflete as diferentes experiências de vida dos diferentes povoados. São olhares, interpretações e imagens variadas que fluem e coexistem nos diferentes ambientes do que chamamos "a cidade contemporânea". No entanto ainda hoje me pergunto, após quatro anos de "trabalho de campo" intenso e de vivência cotidiana, como fez o escritor Érico Veríssimo ao se despedir do México: "Quantos anos precisarei para digerir o México? Quantas vidas devia viver para compreendê-lo? Mas um consolo me resta e basta. Não preciso nem minuto para amá-lo".

Na cidade do México nasceram meus dois filhos, Sofia e Carlo, nos anos de 1997 e 1998, respectivamente. Meus dois amores, meus companheiros de jornada. Um sonho realizado. São tantas as partilhas e afetos ao longo das nossas vidas, que não conseguiria descrevê-los, não caberia nas letras, mas que permitiram não só levar a tão complexa e extensa vida acadêmica, como transformar a vida em algo ainda mais belo, leve e alegre. É claro que tudo isso implicou em renúncias, entregas, saudades, afastamentos, cumplicidades e batalhas que somente foram vencidas com o apoio incondicional dos meus filhos.

\section{NAVIS}

Imediatamente na volta do doutorado, criei o NAVIS, Núcleo de Antropologia Visual aprovado no departamento de antropologia e depois no CCHLA/UFRN e finalmente em 2001, como Grupo de Pesquisa junto ao CNPq, sendo certificado pela UFRN ${ }^{5}$.

As pesquisas do NAVIS têm privilegiado especialmente temáticas sobre antropologia urbana, antropologia audiovisual e Imagens e novas tecnologias. O NAVIS é um espaço de pesquisa, interlocução e diálogo entre os pesquisadores e deste com a sociedade envolvente sobre temáticas e questões relativas à imagem e às cidades. Abrange um vasto campo de estudo, e que, de forma integrada buscou criar espaço para construção e socialização de novos saberes; promover a formação continuada de professores e pesquisadores; desenvolver novos caminhos para o processo de construção do conhecimento ${ }^{6}$. 


\section{UFRN - ATUAÇÃO INSTITUCIONAL}

O ano de 1994 tomei posse na Universidade Federal do Rio Grande do Norte. Na UFRN, logo assumi na graduação as disciplinas de Introdução à Antropologia, Natureza e Cultura, Teoria Antropológica, Etnologia Brasileira. Naquela época a UFRN vivia uma fase de caracterizada por uma política de expansão e na defesa da educação. A UFRN procurava ampliar o desenvolvimento de projetos inovadores de modo a contribuir para o alargamento das fronteiras do conhecimento, modernizar a gestão universitária integrando estruturas organizativas, o que resultou no incentivo e na criação de novos programas de mestrado e doutorado.

Nesses primeiros anos na UFRN, em 1995, conheci uma mulher com muita agência e empoderamento, que foi muito importante para conhecer o "Nordeste profundo". Ilda Ribeiro de Souza, conhecida como Sila. Ela fez parte do bando de lampião, amiga de Maria Bonita e casada com Zé Sereno. A memória das mulheres do cangaço não pode ser esquecida. Mergulhei nas leituras sobre o sertão brasileiro, organizei um roteiro, participei de um edital e propus a Sila realizar de forma partilhada um documentário sobre o universo feminino na construção do que hoje conhecemos por Cangaço. Como viviam as cangaceiras nas décadas de 1930 e 1940 e quais as razões que as levaram para essa vida; como algumas mulheres ingressaram nos bandos, se foi de forma voluntária ou coagidas e privadas do convívio com seus familiares. Sendo assim, percorremos o mesmo trajeto do bando de Lampião, visitamos Mossoró (túmulo de Jararaca), Juazeiro do Norte (terra de padre Cícero), Serra Talhada (onde nasceu Lampião), Poço Redondo (onde nasceu Sila) e Grota de Angicos (local de massacre). Esse documentário ganhou prêmio de melhor vídeo universitário no Rio de Janeiro e contou com apoio da TVU e do músico Babau na trilha sonora. Foram dias intensos, ouvindo histórias, cozinhando, dividindo a mesma cama e pintando os cabelos de Sila, prestando atenção em cada gesto, trejeitos. E assim me deixei mudar pela experiência. E foi esse o olhar que eu escolhi para cada tema de pesquisa, em cada bairro, em cada comunidade eu procuro ver o que torna a vida possível.

De lá para cá, novos desafios se apresentaram e emergiram, todos a exigir enfrentamento com perseverança e empenho institucional para assegurar a qualidade do ensino, dentro desse contexto e com a proposta de fortalecimento e desenvolvimento da área de Antropologia no âmbito da Universidade Federal do Rio Grande do Norte, empenhei-me no projeto coletivo de criação do Departamento de Antropologia em 2000, na criação do PPGAS em 2005 e do doutorado em 2014. Durante catorze anos integrei o corpo docente do PPGCS, lecionando, orientando e participando de atividades e comissões desse programa.

Desde então, venho participando plenamente das discussões pertinentes ao curso de graduação em Ciências Sociais (bacharelado e licenciatura), participando de comissões e ministrando disciplinas. Entre as disciplinas ministradas na graduação de Ciências Sociais, cito: Introdução à Antropologia, Teoria Antropológica IV, Antropologia e o Estudo da Cultura, Antropologia Urbana, Cultura Brasileira, Antropologia e Imagem, entre outras. A disciplina Antropologia e Imagem foi elaborada para um novo ementário do Curso de Ciências Sociais. Inaugurei seu programa dando forte ênfase ao estudo da imagem e da prática audiovisual.

Minha contribuição como docente na área de Antropologia e, a seguir na área da Antropologia e Imagem, foi ensinar as metodologias de uma produção audiovisual e sobre a análise de imagens, e sem descurar da reflexão sobre a sociedade e a cultura. 
Ao longo desses vinte e dois anos de trabalho na UFRN, tenho trabalhado na Graduação em cima de currículos que foram redimensionados e da criação de disciplinas. Lecionei na Graduação todos esses anos, com interrupções apenas durante os quatro anos do meu doutoramento (1996-1999) e do ano em que estive ausente para Estágio Pós-Doutoral (2008).

Participei de debate da reforma curricular, coordenei o segundo curso de especialização em Antropologia na Cidade: Teoria e Trabalho de Campo, Fui Vice Coordenadora do Curso de Ciências Sociais, e em 2011 assumi a Chefia do Departamento de Antropologia. Fui responsável pela implantação junto com os demais colegas da criação do Departamento de Antropologia, da pós-graduação e doutorado em Antropologia. Gostaria de destacar que o projeto de criação do mestrado e do doutorado em Antropologia contou com a participação ativa de todos os colegas. Naquela época a equipe formada pelos professores: Anita Queiróz Monteiro, Terezinha Martins, Elisete Schwade, Luis Assunção, Julie Cavignac, Eliane Tania, Luciana Chianca, Carlos Guilherme Octaviano do Valle. Depois, somaram-se ao departamento os professores Rita de Cássia, Rozeli Porto, Juliana Melo, Glebson Vieira e Angela Facundo, e mais recentemente Paulo Vitor Leite Lopes. Durante esses anos contamos com professores substitutos, visitantes e bolsistas Procad/Capes. Todos os projetos realizados no Departamento foram projetos coletivos, exigindo a dedicação e empenho e todo corpo docente, bem como dos técnicos administrativos, Adriano Aranha Freire e Gabriela Bento da Cunha, que também agradeço. Não acredito em trabalho acadêmico sem trabalho em equipe.

Fiz parte do corpo docente dos seguintes cursos de especialização: Relações Interétnicas (2012); do Curso de Especialização em História e Cultura Afro-brasileira e Africanas, disciplina Racismo no Brasil e as Produções de Verdades e do Curso de Especialização em Cinema (2014 e 2015), responsável pela disciplina Cinema e Documentário. Atualmente faço parte da comissão que integra o projeto para a criação do curso de Pós-Graduação em Cinema na UFRN.

Por fim, com alunos de Graduação já propus etnografias urbanas no centro histórico da cidade de Natal, nos bairros da Rocas, Tirol, Petrópolis, Cidade Alta, nas praias urbanas, Pedra do Ingá (PB) e Lajedo de Soledade (RN).

Já na Pós-Graduação de Ciências Sociais lecionei as seguintes disciplinas: a Cidade e o Urbano; Antropologia Urbana; Tópicos Especiais - Teorias Pós-Coloniais e Imagens; Cidade, espaço e territórios; Seminário de pesquisa; Teoria Social, entre outras. Participei como professora e orientadora de mestrado e demais atividades relacionadas ao Convênio MINTER-PPGCS-UNIT (Universidade de Tiradentes, Aracaju, SE).

Na Pós-graduação em Antropologia, desde sua criação tenho participado de diferentes comissões e ministrado as seguintes disciplinas, destacaria: Antropologia Urbana, Antropologia e Imagem e Seminário de Pesquisa. Participei ativamente dos convênios PROCAD UFR /Museu Nacional 2007; PROCAD/NF 2014 UFRN, UFSC e UFAM 21/2009 - CAPES, período 2010-2014 e o PROCAD/Casadinho. UFRN/UNB - período 2014-2016. Destacaria entre as inúmeras atividades desenvolvidas nesses projetos a recente publicação do livro Trajetórias antropológicas, encontros com Gilberto Velho, com Cristina patriota (UNB).

Ao longo dos 22 anos de carreira, foram orientados 29 trabalhos de conclusão de graduação e 10 (dez) alunos de iniciação científica, incluído voluntários ou com bolsas de Iniciação Científica do CNPq (IC e PIBIC). Além dessa longa experiência na formação científica de alunos que se dirigiam para 
o mercado de trabalho ou para programas de pós-graduação no país, concluí a orientação de 24 dissertações de mestrado e oito (08) teses de doutorado e seis (6) especialização.

Faz-se importante destacar que vários dos trabalhos dos meus orientandos foram publicados em livros e com excelente repercussão acadêmica. Também gostaria de realçar que a grande maioria dos meus orientandos estão inseridos no mercado de trabalho, principalmente em Universidades ou Institutos Federais.

Desde então, participo em comissões de bancas de mestrado, de doutorado, qualificação de mestrado, qualificação de doutorado, banca para concurso púbico para professor efetivo, banca para professor substituto, bancas de seleção de mestrado, seleção de doutorado, entre outras. Além das atividades citadas, participo de várias outras atividades acadêmicas, seja ligada ao Departamento de Ciências Sociais, ao Departamento de Antropologia ou a outras instituições. Entre as comissões que participei, já fui membro da câmara de pesquisa e pós-graduação do Conselho Departamental do CCHLA, membro do colegiado do curso de Ciências Sociais e membro do Comitê Consultivo de Extensão da UFRN, membro do Comitê de Organização da CIENTEC, membro do Comitê do NAC, e mais recentemente, membro do projeto estruturante Mais Cultura da UFRN, responsável pelo projeto CINE UFRN.

A minha participação na organização de eventos tem sido, majoritariamente, na condição de coordenadora de grupos de trabalho que reúnem os pesquisadores da linha de audiovisual, atuando na seleção dos textos e na organização das sessões nos seguintes fóruns: ABA, ABANNE, REA. E estou regularmente apresentando trabalhos em eventos de antropologia do país e do exterior, como: ANPOCS, ABA, ABANNE, REA, Congresso Luso Brasileiro, APA, entre outros.

Foi Membro da Comissão de Elaboração e de Avaliação do Roteiro de Classificação da Produção Audiovisual/CAPES. Membro da Comissão da Imagem e Som da ANPOCS nas gestões 2001-2002 e do GT Antropologia Visual da ABA (2009-2010) e (2011-2012). Fui editora da Vivência Revista de Antropologia e membro do Conselho Editorial de outras revistas científicas. Além de conselheira, emito regularmente pareceres para essas revistas e ainda para outras que me procuram para atuar como avaliadora ad hoc.

Fico muito feliz de ter encontrado espaço para trabalhar na UFRN em função das minhas linhas e, principalmente, lugares de pesquisa, mas ressalto que não foi fácil, foi através de muita persistência e determinação. Gostaria de destacar a recepção do professor Luís Assunção, Anita Queiroz Monteiro e Maria da Conceição Almeida. Esses professores apontaram caminhos, ampliaram meus horizontes e me incentivaram a transformar minhas inquietações em perspectivas intelectuais. Minha gratidão.

Acredito que a minha experiência tenha tido um impacto positivo na formação dos alunos, pois muitos deles se tornaram pesquisadores e professores universitários, além do estímulo a uma tradição de pesquisa acadêmica no ambiente do Departamento de Antropologia. Os projetos desenvolvidos têm

274 resultado em publicações individuais e em coautoria com colegas dos outros departamentos, com colegas de outras instituições universitárias, além de alunos de doutorado e mestrado. 


\section{CONFISSÕES METODOLÓGICAS}

A meu ver, a Antropologia, ao lado de muitas realizações, é desafiada a recriar seus procedimentos, submetendo muito do conhecimento acumulado à crítica e avançando para novos horizontes. É instigante pensar que, neste exato momento, novas questões são postas, novos questionamentos são gerados, em diferentes locais e em diferentes línguas.

Lembro-me nesse momento que em sala de aula costumava oferecer aos calouros a leitura de textos etnográficos, dentre os quais, "Os ritos corporais dos naciremas", de Horace Miner, para que o aluno perceba o estranhamento (mesmo que de forma artificial). E, como não poderia deixar de ser, a introdução do livro "Os Argonautas do PacificoPacífico Ocidental", de Malinowski, cujo objetivo é mostrar a importância do trabalho de campo no sentido clássico do termo.

Hoje eu percebo a Antropologia como a arte da escuta. Entendo a Antropologia como um ato de entrega. Resultado de um envolvimento intenso entre quem fala e quem escuta fundado através de uma relação de confiança mútua. Colocando-se ao encontro desse argumento, Peirano (2008) aponta que etnografia não é apenas uma metodologia ou uma prática de pesquisa, "mas a própria teoria vivida [...]. No fazer etnográfico, a teoria está, assim, de maneira óbvia, em ação, emaranhada nas evidências empíricas e nos nossos dados." (PEIRANO, 2008, p. 3). Teoria e prática são, pois, inseparáveis.

Para John e Jean Comaroff (1992), etnografia é "um modo de compreender contextos situados historicamente, cada qual com seus próprios, talvez radicalmente diferentes, tipos de sujeitos e subjetividades, objetos e objetivos" (COMAROFF, 1992, p. 9-10).

No trabalho de campo que realizei nas cidades fronteiriças, neste caso, Tijuana (México-EUA), foi possível descobrir uma nova forma de estilo de vida, não prevista pelas hipóteses iniciais do projeto original. Uma nova forma de fazer música, uma nova forma de se vestir, uma mescla, um multiculturalismo, como uma nova forma de organização própria dessas zonas. Isto também foi possível identificar no contato direto com os interlocutores. Foi o olhar paciente do etnógrafo que permitiu aprofundar as "pistas" sugeridas, a partir dos arranjos dos próprios sujeitos.

Com base nas observações dos autores citados e de muitos outros que refletiram sobre o seu trabalho de campo, assumi a cidade como lugar e objeto privilegiado de estudo.

Sei que houve mudanças importantes quando se começou a fazer Antropologia das sociedades complexas. Cambiaram o lugar e o objeto da pesquisa. O antropólogo passou a estudar a sua própria cultura, que é a cultura da cidade, a cultura do urbano.

Na cidade, as experiências são vivenciais. No início do século XX, Georg Simmel (1979) advertia para as influências do crescimento das cidades, ou seja, para a influência de um novo tempo e um novo espaço na formação das metrópoles. A cidade consiste em um palco privilegiado de experiências cotidianas. Um mergulho sobre a cidade pode surpreender. O simples ato de caminhar por uma cidade, pode proporcionar muitas reflexões.

Michel de Certeau (1994) em sua discussão sobre espaço e apropriações dos espaços das cidades pelo que denominou o homem ordinário ou comum, define a noção de espaço como "lugares praticados". De Certeau nos apresenta as diferentes apropriações cotidianas dos espaços urbanos como 
reescrituras das cidades. $\mathrm{O}$ espaço urbano pode ser definido tanto pelo caminhar cotidiano dos citadinos, para retomar o termo de Agier (2011), quanto pelas múltiplas narrativas construídas sobre esse mesmo espaço. Enfim, pelas múltiplas práticas culturais que nele se articulam. Por outro lado, podemos pensar também sobre o tempo e a memória, pois é no espaço que a memória constrói suas ancoragen, como diz Bachelard.

Para Caiuby (2008) "o mundo de hoje é, cada vez mais, um mundo de imagens e de interatividade", a Antropologia até pouco tempo tinha sido, predominantemente, uma disciplina de palavras: uma disciplina na qual se fala, sobre a qual se escreve, e que se lê. No campo da Antropologia Audiovisual Brasileira, entre os autores que refletem sobre o lugar da Imagem e da história da Antropologia, destacaria Clarice Peixoto (1999), que revela, através de suas experiências, como apresentar cinematograficamente os resultados de uma pesquisa; Eckert e Rocha (2014), que propõem uma etnografia da duração nas etnografias urbanas; Carmen Rial (2008), "clubes globais"; Satiko e Caffé (2014), que falam sobre a "ausculta audiovisual" na produção audiovisual; e Ana Lúcia Ferraz (2010), que discute a noção de tempo nos filmes etnográficos.

Na minha pesquisa sobre a cidade de Natal, sobre os bairros de Ponta Negra e o bairro das Rocas (Natal-RN), tenho problematizado algumas questão sobre a escuta e a escrita, o oral e o visual, e principalmente sobre estratégias metodológicas na produção audiovisual. Sendo assim a minha produção intelectual resulta dos projetos de pesquisa, ensino e extensão que tenho coordenado ou participado, materializando-se em: artigos em periódicos, capítulos de livros, livros, conferências, palestras, documentários, filmes etnográficos, discos, registros sonoros, sites ou web pages, CD-ROM's, etc.

\section{PESQUISAS}

O primeiro projeto de pesquisa na UFRN foi realizado sob o título "A cultura no urbano: a comunidade do Lajedo de Soledade (Apodi, RN)". O objetivo desse projeto era ampliar o universo de estudos sobre comunidades negras no $\mathrm{RN}$ e levantar algumas considerações sobre o uso da imagem na pesquisa, assim como retomar o debate sobre a necessidade de buscar e explorar novas formas de transmitir o conhecimento etnográfico. O local onde o projeto foi realizado chama-se Soledade, distrito do município de Apodi, conta com uma população estimada de 3.500 pessoas, merecendo destaque o sítio arqueológico Lajedo de Soledade. O sítio conta com 110 hectares desde a comunidade de Soledade até a fronteira com o Ceará. A inserção na comunidade do Lajedo se deu através da percepção rural/urbana, utilizando a fotografia como principal suporte para a tarefa. Naquele momento, as fotografias das inscrições rupestres foram utilizadas para estimular a memória e o imaginário dos moradores, visando perceber, assim, a sua relação com o patrimônio cultural. A comunidade do Lajedo caracteriza-se pela origem afro-indígena, constituindo-se a partir de três famílias: os Avelino, os Costa (Bruaca) e os Targino. Através da comparação das memórias dos velhos com os registros disponíveis (leitura de Câmara Cascudo, historiadores locais, entre outros) que confirmam que os negros vieram originalmente do Recife, registramos justamente o contrário, que a chegada dos negros ao $\mathrm{RN}$ foi através do porto de Areia Branca e do Ceará (cidades vizinhas de Apodi). As narrativas sobre a origem do lugar estão associadas às grandes secas que dizimaram o gado e o algodão no início dos anos 30 e nos meados dos anos 40. Ainda através dos depoimentos dos moradores mais antigos, percebemos que a implantação da indústria de cal, representou no imaginário local, sinal de progresso e de modernidade. A partir dos anos 80 , surgiu um movimento de preservação e conscientização junto à comunidade, desenvolvido 
pela Petrobras e arqueólogos da UFRN. Esse trabalho resultou na Fundação da Associação Amigos do Lajedo (FAL) e, posteriormente, na criação do Museu Amigos do Lajedo. Atualmente, encontramos por parte daqueles que apostam na preservação e na interiorização do turismo - a Petrobrás, empresários ligados ao turismo ecológico, e a FAL.

Diante de uma situação nova - muitos dados e muitos desafios percebi que a memória e o imaginário das cidades, principalmente do Nordeste brasileiro, têm sido redimensionados em função do novo, do moderno, do turismo. Nota-se também que uma comunidade que não conhece a si mesma dificilmente poderá comunicar a importância do seu patrimônio, portanto é importante refletir sobre a produção de subsídios conceituais que possam orientar a implantação de políticas de promoção e valorização das culturas. Através desta pesquisa, constatamos que a aceitação à apreensão do conceito do patrimônio cultural depende de uma ação cultural e educativa.

Em 2004, iniciei outro projeto, "Imagens e discursos sobre as cidades latino-americanas", cujo foco era modernidades e intervenções urbanas: as imagens e os discursos sobre as cidades (Natal, RN) mais amplo, sobre turismo e patrimônio cultural na cidade do Natal.

Natal é uma cidade litorânea turística de porte médio que, inicialmente, passou a receber os migrantes do interior norte rio-grandense, depois chegaram os estrangeiros: os franceses, os portugueses, os holandeses. A partir de Segunda Guerra Mundial, passou a receber os militares das forças armadas dos Estados Unidos. A paisagem urbana da cidade vem sofrendo mudanças significativas em decorrência do acelerado processo de urbanização e do advento do turismo. Dessa forma, o objetivo do trabalho era mostrar os tipos de intervenções urbanísticas e entender como isso produz um simbolismo no espaço urbano, onde os nexos entre o local e o global se configuram de modo mais rápido e intenso.

A partir daquele período foi crescente a evolução urbana de Natal. A cidade expandiu-se e continua crescendo a cada dia. Nos anos 80, a Via Costeira foi implantada, com uma ampla rede hotéis, pousadas e restaurantes. A atividade turística, aliada ao processo de urbanização e ao crescimento populacional, provocou uma reorganização do espaço. Os bairros centrais se expandiram em direção aos outros eixos e avenidas (Prudente de Morais, Roberto Freire, Bernardo Vieira), enquanto a cidade crescia sem uma legislação atuante.

No entanto o detalhe continua lá. Imutáveis e permanentes quase sempre, alguns elementos resistem numa teimosa necessidade de se manterem incorporados às ruas e pessoas da cidade, encobertos por uma névoa de displicência de quem os usa, transita, esbarra, sem sequer dedicar um segundo de sua atenção para notá-los ou agradecer por sua existência em alguns casos. A área central da cidade do Natal é cheia de detalhes e intervenções pelos quais foi sendo construída, criando sua identidade e deixando as marcas de quem os inventou - podemos assim dizer, fazendo da história da cidade.

A partir da pesquisa elaborada, foi possível perceber o valor histórico, artístico, arquitetônico das obras analisadas, remanescentes raros da arquitetura moderna em Natal, bem como a urgência em tornar público o estado de descaracterização e abandono de alguns destes imóveis. E como os órgãos de preservação locais e nacionais têm muito a fazer para não permitirem a destruição dos registros documentais e obras de valor inestimável para a histórica e memória brasileiras. Trata-se de projeto intitulado $\mathrm{O}$ uso da imagem na pesquisa social. Através do mapeamento e do registro fotográfico percebemos que na área central de Natal, as casas que foram construídas nos anos 1950 e 1960, adotam, grosso modo, aquelas características arquitetônicas da primeira metade 
do século XX: o rechaço da imagem tradicional da casa, em favor de uma aparência abstrata, conformada em um sólido geométrico simples; grandes áreas envidraçadas em fachadas desprovidas de ornamentação; linhas horizontais e o tradicional telhado descartado. Com pilares com formas em "V" muito usadas pela arquitetura paulista e carioca nos anos 50 e muito difundida pelas revistas de época, principalmente a "O Cruzeiro"; platibandas que escondem a cobertura em telha de barro francesa e que ornamentam a fachada com frisos horizontais e verticais, ainda numa semelhança do estilo Art Déco; falsas platibandas inclinadas para lembrar o telhado em borboleta; elementos inclinados na fachada frontal, para quebrar a forma reta do edifício, dentre outros elementos, são muito encontrados na arquitetura popular, geralmente feita sem arquitetos ou engenheiros e que os construtores realizavam obedecendo quase que a uma ordem do proprietário.

No decorrer da pesquisa, deparamo-nos com um movimento "S.O.S. Ponta Negra" que trouxe novos dados para a pesquisa e um redimensionamento da mesma. Assim, uma discussão importante sobre patrimônio, preservação, turismo e urbanização desenfreada nos levou a discutir o patrimônio imaterial junto à comunidade de pescadores e rendeiras - antigos moradores da vila de Ponta Negra. Essa experiência nos proporcionou verificar, novamente, a importância da prática da interpretação do patrimônio e de como este instrumento é fundamental para o desenvolvimento cultural das comunidades.

A partir daí, uma outra pesquisa surgiu "Bairros na Memória: Ponta Negra, Natal, RN" que enfoca as transformações urbanas no bairro de Ponta Negra e os impactos no cotidiano de seus habitantes.

No nordeste do Brasil, na Cidade de Natal, uma antiga Vila de Pescadores vive atualmente uma nova realidade: a demolição de casa antigas, a construção de flats e de condomínios fechados, bem como a verticalização dos prédios. A antiga Vila de Pescadores ou "Vila de Ponta Negra", que deu origem ao bairro, está sendo transformada num ritmo bastante acelerado. A população antigamente era constituída de pescadores que construíram suas casas de palha à beira-mar, sobrevivendo, durante muito tempo, do pescado e também do roçado. Foi a partir da Segunda Guerra Mundial que a Vila rompe com seu isolamento, com a chegada dos equipamentos urbanos e a instalação de balneário militar na praia. Mas foi nos anos 60 que a povoação sofre um processo de urbanização, tendo como base a casa de veraneio. Esse processo intensificou-se nos anos 90, quando o bairro sofre modificações significativas: a verticalização dos prédios, a especulação imobiliária, o turismo sexual, o tráfico de drogas e a prostituição. Esse novo cenário tem provocado mudanças significativas na forma de viver e de trabalhar dos moradores, bem como em sua sociabilidade e lazer. O número de hotéis, pousadas, restaurantes, casas noturnas, albergue, locadora de veículos, mercados é expressivo. Um exemplo bastante visível dessas transformações socioespaciais é a verticalização do bairro, com a construção de grandes empreendimentos imobiliários. Também há um acelerado aumento de flats e de condomínios fechados. Nota-se um forte investimento da construção civil nesse espaço, o que traz como consequência a valorização de terrenos e das residências e a saída de antigas famílias moradoras da Vila, que passam a vender seus terrenos e casas, pela valorização imobiliária do mercado local.

Percebi que o bairro vivia outro ritmo, atraindo um número de novos moradores, muitos deles vindos de outras cidades grandes. Esse fenômeno migratório é apontado como típico da Classe Média Brasileira. Apesar do forte investimento da Construção Civil - e, consequentemente, a valorização de terrenos e das residências - estar provocando a saída de antigas famílias moradoras da Vila, que passam a vender seus terrenos e casas, pela valorização imobiliária do mercado local, isso não ocorre de modo geral. $\mathrm{O}$ depoimento 
de Ronaldo, morador da Vila e filho de pescador, é muito significativo: "Não tem gringo que me tire daqui não. Nasci aqui e vou morrer aqui, com certeza. Nascido e criado e aqui continuarei até à morte".

A minha intenção em centrar a pesquisa em Ponta Negra era, através do olhar atento, observar todos os tipos de intervenções urbanísticas, para entender o simbolismo daí resultante, no espaço urbano, onde os nexos entre o local e o global se configuram de modo mais rápido e intenso.

Cabe aqui fazer algumas referências a esse tema. A utilização dos recursos audiovisuais na investigação de campo levantou uma discussão interessante: o próprio descaso com a imagem - a fotografia durante muitos anos foi usada apenas como ilustração. Essa situação também revelou a origem literária do discurso científico. Mas vale lembrar que, na Antropologia, desde o início do século XX, a fotografia já fazia parte do trabalho de campo dos antropólogos (Malinowski, Margaret Mead, Gregory Bateson e Evans Pritchard), que utilizavam a imagem para análise cultural do comportamento.

Nas páginas seguintes, fotografias que mostram as transformações urbanas no bairro de Ponta Negra, em Natal:

Imagem 1 - A Vila começo dos anos 30

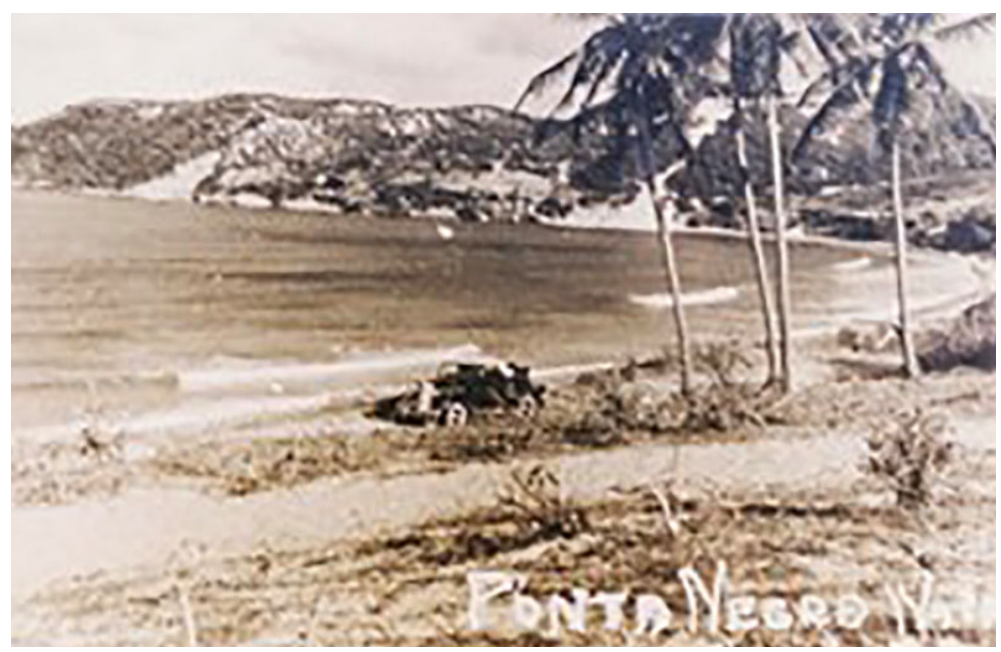

Fonte: Fotógrafo Esdras. Acervo NAVIS.

Imagem 2 - Anos 40: a chegada dos norte-americanos

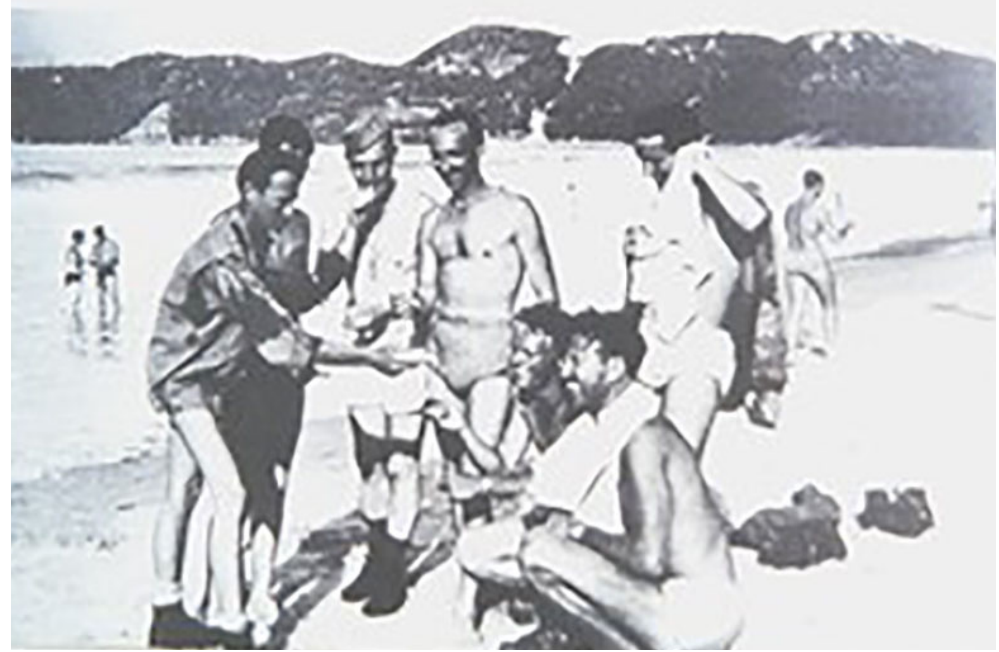

Fonte: Jornal Tribuna do Norte. Acervo NAVIS 


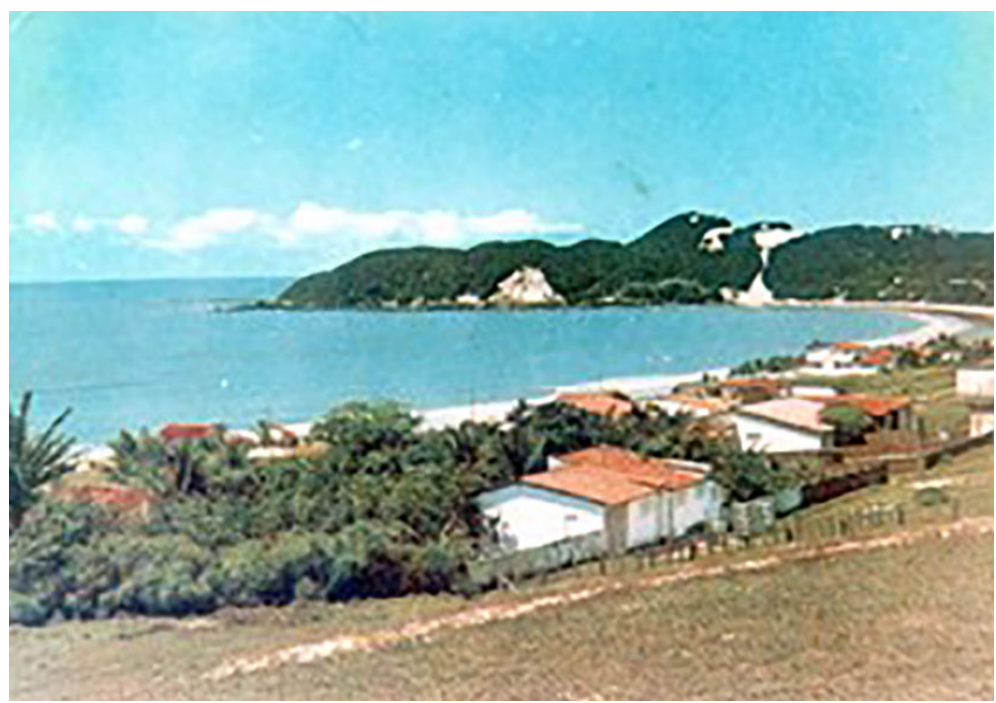

Fonte: Fotógrafo Esdras. Acervo NAVIS.

Imagem 4 - Século XXI: verticalização do bairro

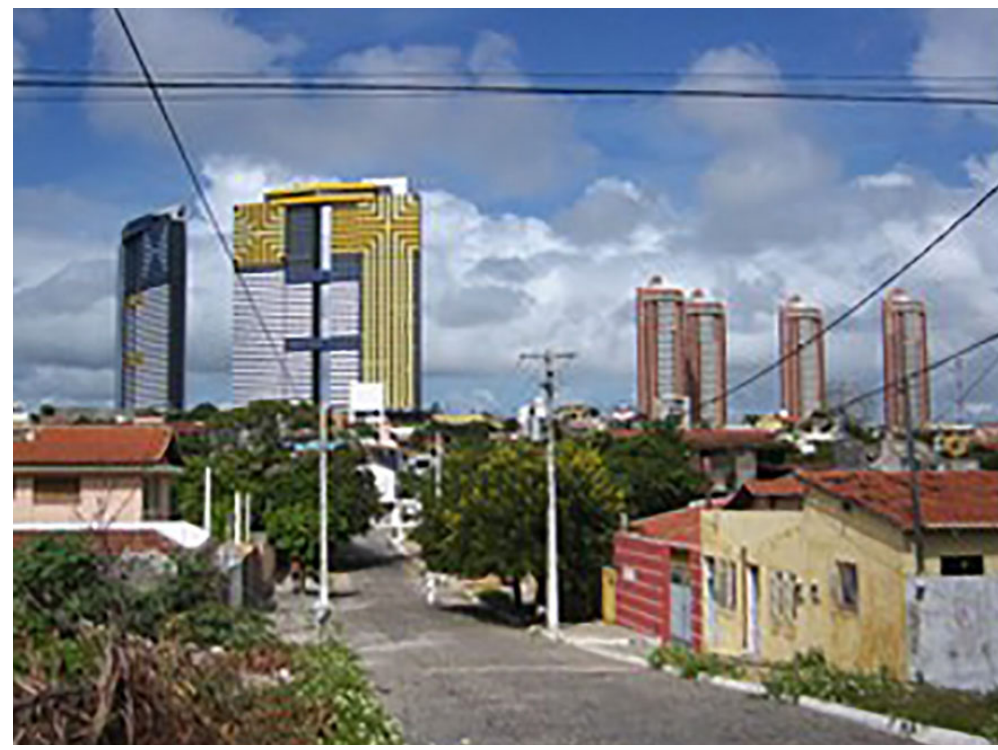

Foto: A autora. Acervo NAVIS

A meu ver, as imagens não apenas são modos de ilustrar um texto escrito considerado propriamente como etnográfico. As fotografias/filmes são resultados de encontros etnográficos e de perspectivas teóricas. Trata-se de uma produção imagética que nos reenvia a questões crucias sobre o modo que se produz o conhecimento na Antropologia ${ }^{7}$.

O foco de minha produção intelectual mais recente é refletir sobre metodologias audiovisuais participativas. A construção de narrativas, os interesses dos participantes na pesquisa, e o acesso destes aos objetivos, métodos e meios de investigação e a legitimação, pela academia, dos saberes e expressões locais e orais. Participativa a partir de leituras de BLACKMAN, 2007; LORENZ; KOLB, 2009; LYKES, 2001; PRINS, 2010; o Photovoice (WANG; BURRIS, 1997), o vídeo participativo (HARRISON, 2002) e até o desenho (BOLTON; POLE; MIZEN, 2001) e os quadrinhos com o comic voice (BAIRD, 2010) como suportes imagéticos. 
Poderia continuar com outros exemplos de pesquisas e o uso de imagens que realizei ao longo dessa trajetória, como a caso do bairro das Rocas, Natal, RN, mas a intenção aqui é trazer exemplos produzidos no âmbito doméstico e sem a pretensão de concluir. Esses são apenas alguns exemplos da dinâmica do processo científico da produção do conhecimento. É interessante pensar que hoje existe um conhecimento, mas que outros virão no futuro.

Essas pesquisas, para mim, tornaram-se um programa de reflexão sobre determinadas categorias de pensamento às quais venho me debruçando: memória, patrimônios, conjuntos urbanísticos, arquitetura, cidades, cultura contemporânea, cinema, fotografia. Procurei ampliar o horizonte de reflexão teórica, dar maior embasamento metodológico e sempre expor claramente os objetivos do meu trabalho, dizendo quem sou, o que faço e a que instituição estou ligada. $^{8}$

Acredito que a discussão sobre o fazer audiovisual me fez avançar no tópico específico sobre metodologias audiovisuais participativas, que é como qualifico meu amplo posicionamento em termos de perspectiva intelectual, de trabalho acadêmico atualmente. Por essa razão, dediquei-me a organizar inúmeras mostra de filmes e oficinas sobre análise fílmica. Sempre apostei na utilização de material audiovisual como um excelente instrumento de resgate da memória e, a partir dos debates, na possibilidade de criar um espaço para a troca de conhecimento entre debatedores e estudantes ${ }^{9}$.

Gostaria de acrescentar a publicação de dois livros com artigos dos meus orientandos, Imagem e Meio Ambiente (2000) e "As cidade e as imagens" (2015). E a terceira publicação, em parceria com a professora Maria Angela Pavan (PRAGMA/DECOM/UFRN), com o título "Narrativas, memórias e itinerários" (2018).

Em 2008, realizei pós-doutorado na UFSC, cujo resultado foi bastante positivo e, um dos resultados desse intercâmbio junto ao NUER-PPGAS-UFSC, foi a aprovação do projeto intitulado "A trilogia das Novas Famílias": ampliando o debate e o conhecimento sobre a dimensão sociocultural do HIV/AIDS no Brasil e Moçambique”, Edital PRÓ-AFRICA. Em 2009, tive oportunidade de realizar uma pesquisa nos acervos fílmicos em Moçambique, organizar mesa de debates e mostra de filmes brasileiros no Festival Dokanema em Maputo, Moçambique ${ }^{10}$. E que tornou possível a realização do documentário "Moçambique em movimento".

Desde 2009, venho desenvolvendo uma pesquisa sobre cinema africano, com tema migração e diáspora, nos arquivos de imagem e som em Portugal e Moçambique, o que potencializou o meu desejo de retornar às minhas reflexões e à pesquisa sobre o método de captação de imagem e som no audiovisual, que resultou na produção de artigo "audiovisual africano como revolução" (2012) e na organização do Dossiê: Corpo. Identidades sexuadas e sexualidades nos cinemas nacionais e transacionais. Revista Bagoas, Estudos gays: gêneros e sexualidades (2015).

\section{NARRATIVAS, MEMORIAS E ITINERÁRIOS}

Atualmente, estou trabalhando sob a perspectiva da Antropologia Audiovisual Participativa. O foco de minha produção intelectual mais recente é refletir sobre metodologias audiovisuais participativas; a construção de narrativas, o interesse dos participantes na pesquisa e o acesso destes aos objetivos, 
métodos e meios de investigação e a legitimação, pela academia, dos saberes e expressões locais e orais.

As imagens não são apenas modos de ilustrar um texto escrito considerado propriamente como etnográfico. As fotografias/filmes são resultados de encontros etnográficos e de perspectivas teóricas. Trata-se de uma produção imagética que nos reenvia a questões crucias sobre o modo como se produz o conhecimento na Antropologia.

A busca de novas perspectivas teórico-metodológicas, para tanto faz-se através de um questionamento da tendência de construir o conhecimento coletivo e de utilizar a dimensão imagética como documento da "realidade objetiva" ou como mera ilustração de textos verbais. Ressalta-se a importância de dedicar maior atenção aos significados culturais engendrados pelas narrativas e imagens, bem como às formas pelas quais a produção e a leitura dessas imagens são mediadas. Essa nova forma de abordagem transforma a prática de pesquisa e do ensino.

É nesse turbilhão de pensamentos epistemológicos que enveredo por um dos projetos que tive o prazer de coordenar: "Narrativas, Memórias e Itinerários" (PROEXT/MEC, 2014, 2015, 2016) ${ }^{11}$. Nessa travessia, conto com Maria Angela Pavan, professora do Departamento de Comunicação da UFRN. A nosso ver, as narrativas orais e imagéticas devem ser pensadas no sentido de ouvir os interlocutores para que esses possam mostrar através de suas experiências como enfrentam o cotidiano, a discriminação e os estigmas e preconceitos ${ }^{12}$.

Nessas produções audiovisuais, passamos a investigar os itinerários de vida de indivíduos e ou grupos urbanos na cidade do Natal/RN, a partir de suas ações, gestos, vozes. Vozes nem sempre uníssonas, mas reveladoras de interações, tensões e expressões sobre a cidade, entre eles: "No mato das Mangabeiras" (2014), "Seu Pernambuco" (2014) e "Mestre Zorro" (2016) e "as mulheres das Rocas são as vozes do Samba (2015), "Jão e Lua" (2015), "As divas do samba" (2016). Em fase de edição e finalização encontram-se os seguintes documentários envolvendo diferentes bairros da cidade de Natal Rocas, Ribeira e Cidade Praia. E na produção dos artigos: "Documentário e Memória: narrativas, itinerários e o método para uma etnografia da duração na realização do documentário das mangabeiras e as Mulheres das Rocas: imersão do documentário no espaço-tempo dos personagens do samba em Natal/ RN" (2017) ; "Seu Pernambuco" (2016) ; "No mato das mangabeiras: por uma etnografia da duração na construção do documentário" (2016) e "Estratégias Metodológicas na construção de documentários: em campo com as mulheres das Rocas, Natal-RN" (2018) e "No tabuleiro com as coletoras de frutas, como construir um documentário com a extensão do tempo" (2018).

Atualmente sou coordenadora do CAV (comitê de antropologia da ABA) e faço parte da Rede AMLAT como pesquisadora. No ano de 2014, realizei uma visita técnica aos grupos de pesquisa MIGRACION e GRAFOS da UAB em Barcelona a convite dos Professores Nicolás Lorite García e Jorge Grau. Em 2017, realizei o Estágio Pós-Doutoral que me permitiu realizar novos contatos, estabelecer parcerias e construir processos de colaboração com colegas espanhóis e de outras origens que se encontram no laboratório de Antropologia e Comunicação nesta Universidade; ao mesmo tempo, possibilitou a oportunidade de dar visibilidade às pesquisas nacionais, possibilitando a troca de experiências de pesquisa. Como também a organização do dossiê "Antropologia e investigação audiovisual” para a Vivência Revista de Antropologia (2017).

Até aqui acredito que em linhas gerais as minhas áreas de interesse e as atividades realizadas tenham sido esboçadas. Os contatos com diferentes 
grupos de pesquisa no Brasil e fora do Brasil, além de permitirem uma abertura para a construção coletiva e partilhada do conhecimento.

Tenho buscado articular nas minhas pesquisas as cidades, as imagens e cinema. A experiência de docência, além de ser muito importante para avançar de uma forma diferente nas minhas pesquisas, aproximaram-me do ofício de orientadora. Minha participação em bancas de mestrado e doutorado, monografias, exames de qualificações e minha atuação como orientadora tem sido muito gratificante. Minha intenção é que o futuro me ajude a continuá-las, mas isso é o início do fim e o limite desse memorial.

Para concluir, minha família sempre me contou com orgulho as histórias dos avós, das bisavós, dos tios, como eles chegaram, como sobreviveram, o lugar que escolheram para viver. Desde minha infância eu escuto narrativas em terceira pessoa. Há 25 anos sou antropóloga e escrevo sobre a importância da escuta. Ouvir vidas. Enquanto escrevo essas linhas, o Brasil clama por memória, por justiça e por direitos. A discussão está nas ruas, nas universidades, nas escolas, diz respeito à cidadania. De um lado, velhas oligarquias tentando impor novas medidas, como a PEC 241/2016, que é uma ameaça à educação, à saúde e às universidades públicas. Por outro, um movimento de resistência, que clama por um futuro digno. É nesse movimento que eu acredito.

Imagem 5 - Gravação do CD Mestre Zorro no estúdio Beju Produção, Natal, RN

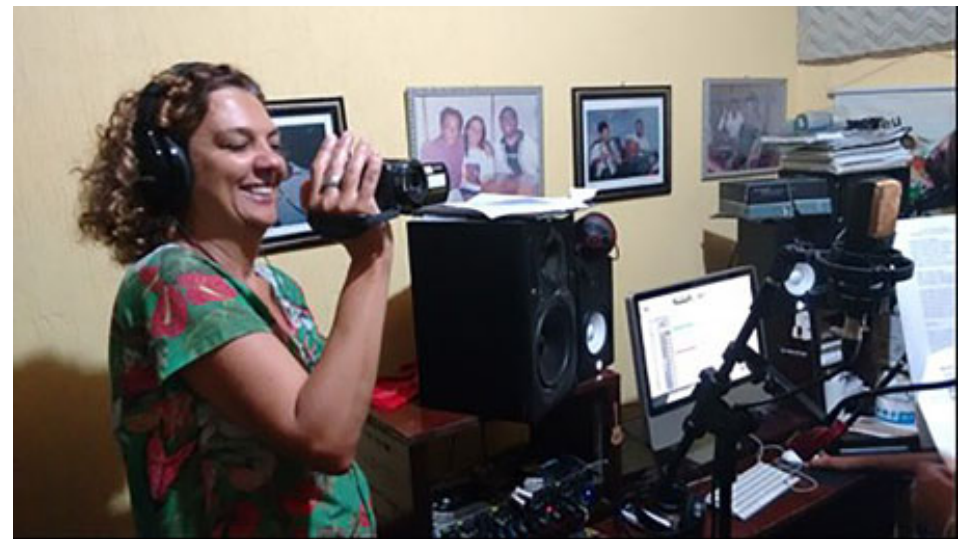

Fonte: Foto Beatriz Cortez Tanabe. Acervo NAVIS.

\section{DOCUMENTÁRIOS E VÍDEOS ETNOGRÁFICOS}

Mestre Zorro - direção Lisabete Coradini e Maria Angela Pavan, Proext/MEC, UFRN, 2015 - O samba nasceu nas Rocas e o Zorro nasceu no samba. Heriberto Pedro da Silva, mais conhecido como mestre zorro, compositor e sambista, considerado um grande nome do gênero samba em Natal. Esse documentário procura narrar a trajetória de vida desse sambista que nasceu em 9 de dezembro de 1952.

As mulheres das rocas são as Vozes do samba, 20 min, direção Lisabete Coradini e Maria Angela Pavan, Proext/MEC,UFRN, 2015 - Vozes do samba narra a história de cinco mulheres do bairro das Rocas. Elas são as guardiãs das memórias do samba local. Além de detentoras da história, têm papel ativo desde o início na construção das escolas de samba em Natal-RN. Para realizar o documentário, nós nos envolvemos com os acontecimentos locais durante quatro anos. E dessa forma, construímos um arquivo de fatos e 
entrevistas para documentação da história do samba. Entre lembranças, fotos, imagens e músicas, nós nos relacionamos no espaço-tempo de cada entrevistada, e o audiovisual permitiu essa relação intensa, que possibilitou um conhecimento ativo na vida das mulheres do samba das Rocas em Natal/RN/Brasil.

As divas do samba 2015. Direção: Lisabete Coradini e Maria Angela Pavan, Proext/MEC, UFRN, 2015 - Entrevista realizada com as quatros divas do samba potiguar: Dodora Cardoso, Glorinha Oliveira, Lucinha Lira e Hélia Braga. Entrevista foi gravada durante o evento "As damas do Samba em Natal", que aconteceu no Barracão da Escola de Samba Balanço do Morro, no dia 9 de agosto de 2015. Homenagem, aos 90 anos, da grande cantora e atriz das rádios de Natal-RN, apelidada por Assis Chateaubriand de " rouxinol potiguar"!

No mato das mangabeiras 2014. Direção: Lisabete Coradini e Maria Angela Pavan, ProextMEC, UFRN, 2015 - Bibia, Maria, Lenide, Inês e Didel. O grupo nativo da Vila de Ponta Negra é pequeno, mas detentor de força e vigor suficientes para buscar no mato das mangabas a aventura que, além de dar retorno financeiro, deixa suas almas e mentes purificadas para enfrentar o cotidiano na Vila de Ponta Negra. Munidos de comida, água, companheirismo amor e coragem, eles mantêm viva a tradição caiçara de coletar mangaba no tabuleiro costeiro de Pium, bairro da cidade de Parnamirim-RN. O itinerário desse grupo começa na Vila de Ponta Negra e termina em Pium onde acontece a coleta do fruto. Acompanhamos a saída de Ponta Negra, a coleta, o armazenamento em caixas e a comercialização da mangaba. Um ritual rico repleto de detalhes através do qual aprendemos um pouco mais sobre a delicadeza da vida.

Seu Pernambuco 2015. Direção: Lisabete Coradini e Maria Angela Pavan, Proext/MEC, UFRN, 2015 - Canto do Mangue, Natal-RN, lugar banhado pelo Rio Potengi. Lugar onde se negocia peixe e onde tudo começou na história da cidade. Temos também um maravilhoso pôr do sol - um dos mais lindos do Brasil. E lá encontramos o Bar do Pernambuco, que inebria os cinco sentidos: os aromas e ventos marinhos que chegam com os barcos de pesca, o peixe frito no óleo de dendê, a ginga com tapioca e uma água de coco sempre gelada. O maior nutriente desse lugar é o sorriso de Pernambuco, um senhor de 89 anos com muita vitalidade e sapiência, comanda de domingo a domingo o fogão e afirma que não vive sem o seu trabalho. O bar do Pernambuco é o santuário da história do Canto do Mangue há 55 anos. E como é bom ouvir cada memória e lembrança desse senhor que tem muito a nos contar.

Jão \& Lua. Direção: Lisabete Coradini, Proext/MEC, UFRN, 2015 A partir de uma abordagem antropológica, urbana e visual, buscamos interpretar o vínculo existente entre as intervenções gráficas e o espaço público urbano. Através do depoimento de dois grafiteiros, procuramos evidenciar as intervenções no espaço urbano na cidade do Natal (RN), onde o olhar é uma forma de aproximação, o mundo é aquele que está ao nosso redor, e não "diante" de nós, e o sentido é uma espécie de dádiva a ser negociada .

Moro no се́u. 2013, NAVIS/UFRN — Narra o cotidiano do assentamento Paulo Freire, em Pureza, através do depoimento de seus moradores. A luta pela posse da terra, o roçado e estratégias de sobrevivência.

Moçambique em movimento. 2010, NAVIS/UFRN - Entrevistas realizadas durante o Festival de Cinema Documentário de Moçambique (Dockanema) com três cineastas moçambicanos: Isabel Noronha, Karl de Souza e Licínio Azevedo. Eles falam sobre a dificuldade de se fazer cinema, quais os principais temas e as parcerias com empresas estrangeiras.

O Rei do Mercado. 2008, NAVIS/UFRN — Um documentário realizado durante uma oficina sobre produção audiovisual. Ele retrata a vida de um 
personagem mais populares do Mercado Público de Florianópolis, conhecido carinhosamente como Roberto Carlos.

Vende-se uma ilha. 2007, NAVIS/UFRN - Procura mostra as transformações urbanas na vila de Ponta Negra, Natal, RN. A chegada do turismo, a verticalização e os empreendimentos imobiliários.

As transformações urbanas no bairro de Ponta Negra, Natal-RN. 2005. NAVIS/UFRN - Ensaio fotográfico realizado a partir do acervo pessoal da professora Lisabete Coradini, que registrou durante dez anos as transformações do bairro de Ponta Negra.

25 anos do Programa de Pós-Graduação em Ciências Sociais da UFRN. 2004 - Vídeo institucional, realizado durante as comemorações dos 25 anos do PPGCS da UFRN. Conta com depoimento de professores, técnicos e estudantes.

Lajedo de Soledade. 2003. NAVIS/UFRN — Trata de entender qual a relação dos moradores de Soledade, distrito do município de Apodi, com relação ao sítio arqueológico Lajedo de Soledade. O sítio conta com 110 hectares desde a comunidade de Soledade até a fronteira com o Ceará. As fotografias das inscrições rupestres foram utilizadas para estimular a memória e o imaginário dos moradores, visando perceber, assim, a sua relação com o patrimônio cultural.

Imaginário futurista. 2000. NAVIS/UFRN - Esse documentário apresenta algumas reflexões sobre a cidade modernidade. No período do pós-guerra, a sociedade moderniza-se. As casas possuem equipamentos, como: ferro elétrico, enceradeira elétrica, lavadora, máquina de costurar, ar condicionado, etc. A modernidade indicava novas formas de habitar; modernidade quer dizer condomínios, edifícios sobre pilotis, casas de vidro e de concreto. A modernidade provocava novas formas de ver a cidade e impunha um novo modelo de 'ser urbano moderno'.

Viva lamuerte! 1998. NAVIS/UFRN - Documentário sobre o conceito de morte para os mexicanos, realizado nos dias 1 e 2 de novembro na cidade do México. A festa do Día de Muertos é extremamente festiva, uma das maiores comemorações do país. Para os mexicanos, a morte é uma parte da vida, e não um momento de tristeza. Acredita-se que, na morte, as almas vão para um lugar melhor e por isso não há motivo para chorar.

Sexo dos Anjos. 1995. NAVIS/UFRN — O documentário pretende provocar uma discussão sobre o turismo sexual em Natal e João Pessoa. O comportamento e as relações entre as mulheres e os estrangeiros; os lugares mais frequentados; boates, bares e hotéis; chegada dos voos internacionais e a campanha de denúncia das ONGs Local.

Entre Heróis e Bandidos a mulher cangaceira. 1994. NAVIS/UFRN. Documentário foi rodado na cidade de Poço Redondo, a cento e oitenta e quatro quilômetros de Aracaju, capital sergipana, às margens do Rio São Francisco, com população de aproximadamente vinte e seis mil habitantes e economia voltava para a agricultura e pecuária. Faz parte deste município a grota de angico, palco de uma das maiores atrocidades realizadas pela polícia nordestina: morte e exposição das cabeças cortadas de Lampião, Maria Bonita e nove cangaceiros, na madrugada de 1938. Conta a história de Sila e Zé Sereno, que escaparam do massacre, e foram para São Paulo,1947.

Cruzando caminhos: identidade ilhoa no mercado público de Florianópolis. 1993. NUER, UFSC - O Mercado Público, importante marco histórico-cultural da cidade, é o coração do centro histórico, palco da reunião de 
artistas, boêmios e intelectuais, onde se encontra o melhor em pescado fresco, camarão, ostras. Além de bares e restaurantes. Um ambiente com apresentações artísticas eventuais no pátio central. Registramos o seu cotidiano, as memórias $\mathrm{e}$ as tensões entre os seus mais diferentes frequentadores.

CD interativo Memorias do futuro - Produção realizada a partir do acervo de imagens da Tese de doutorado "Memórias do Futuro". Um recurso didático-pedagógico para auxiliar as discussões em sala de aula sobre cidade. E também de como utilizar as novas tecnologias com imagens fixas, imagens em movimento e texto.

O CD Mestre Zorro e Samba Canguleiro - CD composto por 10 sambas autorais, com a direção musical de Jubileu Filho e Chico Bethoven, produção executiva Lisabete Coradini, arte da capa e encarte de Jean Sartief, arte gráfica de Pedro Gabriel. Gravado BEJU Estúdio, Natal, 2015. Esse CD nasceu do desejo de produzir e difundir novos conhecimentos e novas metodologias participativas e interativas com relação a imagem e som. Faz parte de um grande trabalho de pesquisa (entrevistas, etnografias, ensaios fotográficos, registro audiovisual e sonoro.).

\section{NOTAS}

${ }^{1}$ A elaboração do presente Memorial Descritivo seguiu as recomendações presentes na Resolução n. 136-2014-CONSEPE, de 22 de julho de 2014 que trata do processo de avaliação de desempenho para fins de progressão e de promoção na carreira do Magistério Superior na UFRN. Contudo, em seções específicas do presente memorial fiz referência a minha trajetória desde a graduação no intuito de oferecer uma visão retrospectiva mais ampla para evidenciar as principais linhas de motivação e de evolução das minhas atividades acadêmicas.

${ }^{2}$ Há uma série de escolas e teorias que se dedicam a refletir sobre histórias de vida, autobiografias, trajetórias, tanto do ponto de vista conceitual ou metodológico. São ponto de partida para pesquisas antropológicas - como Bourdieu (1966), que ponta para o caráter ilusório das narrativas biográficas ou Becker (1986), com perspectivas diferentes.

${ }^{3}$ Ao conversar com os frequentadores da praça, detectei, como fazendo parte do imaginário atual, imagens produzidas no passado. Senti a necessidade de fazer uma pesquisa documental e bibliográfica em livros, jornais, revistas e fotografias, com relação ao local. A partir daí, passei a considerar como informantes os autores dos documentos tanto quanto os moradores com quem convivi. Através do enfoque escolhido, o lugar e a fotografia acabaram por colocar em discussão a problemática da construção e da perpetuação da memória urbana. Narrativas e imagens se entrelaçam para contar e recontar a história da praça, dos bairros, da cidade. E assim, deparei-me com um outro tema inovador e polêmico: o uso da imagem na pesquisa social.

${ }^{4}$ Naquela ocasião conheci trabalho de Carmem Rial "Mar de dentro: A transformação do espaço na Lagoa da Conceição" (1988) importante para entender as transformações da cidade de Florianópolis e, principalmente, o debate sobre apropriações do espaço. Esse encontro gerou muitos frutos como a participação de Carmen Rial na minha Banca de defesa de Mestrado, juntamente com o professor J. G. Magnani, que tive a honra de ter como membro externo ao programa. A partir desse encontro com Carmen e Magnani, muitos acalorados debates se sucederam sobre a antropologia urbana e audiovisual.

${ }^{5}$ Para a criação do NAVIS, contei com o apoio do professor contou com a participação dos professores: num primeiro momento com os professores de fotografia Marcelo Andrade (UFRN), Renata Silveira (UFRN) e antropóloga Anita Queiroz (UFRN), realizamos diversas oficinas relacionadas a imagem e pesquisa na penitenciária João Chaves, que resultou num belíssimo ensaio fotográfico Narrativas Visuais de uma comunidade em vias de extinção: Complexo Penal Dr. João Chaves, Natal-RN. Num segundo momento, com a participação das professoras Francisca Miller (UFRN), Ângela Toressan (Granada Center), Edivania Duarte Celestino (IBAMA/UNP), realizamos eventos e minicursos com intenção de discutir o uso das imagens na pesquisa social. E agora, 
num terceiro momento, Gilmar Santana (UFRN), Winifred Knox (UFRN), José Duarte (IFRN), Eliana Tania (UFRN). Além desses pesquisadores, orientandos meus, Chiara Tarsila, Sara de la Rosa, Cristina Santos Ferreira, Alzilene Ferreira da Silva, Ricardo Bruno Campos, Gabrielle Dal Molin, Jean Sartief. e Marilia Melo de Oliveira se filiaram.

${ }^{6}$ Blogs - NAVIS Núcleo de Antropologia Visual da UFRN. Disponível em: https:// navisufrn.wordpress.com/.

${ }^{7}$ Em um trabalho trago uma reflexão mais aprofundada sobre arte de rua, estética urbana e fotografia. Trata-se de um artigo sobre a produção social do espaço urbano na cidade do Natal-RN a partir da leitura das intervenções gráficas, como pichação, pixo e graffiti. Busquei interpretar o vínculo existente entre o autor, a obra e os suportes de tais intervenções. O artigo publicado na Revista de Ciências. Sociais da UFC, com o título "As interferências urbanas na cidade de Natal: um ensaio sobre linhas, cores e atitude" (2016).

${ }^{8}$ Ao longo dos 22 anos de carreira, organizei inúmeros eventos de extensão (roda de conversa, palestras, minicursos, exposições fotografias, mostra de filmes, workshop), Esse organizados pelo Navis com a participação de convidados especiais, como; Etienne Samain, Clarice Peixoto, Fernando de Tacca, Ana Lucia Ferraz, entre outros. Proporcionou debates e reflexões importantes sobre o uso da Imagem na pesquisa social.

${ }^{9}$ Foi com essa intenção que promovemos cursos: oficina "diários etnográficos" com Aina Azevedo; "Familia em Imagens" com Clarice Peixoto; Workshop de documentário com Lilian Solá, entre outros. Em 2012, organizei em parceria com o Festival Goiamum, a Mostra Internacional de Filmes do Caribe; em 2012 e 2013 em parceria com a agente mobilizador Natal e o Instituto Cultura em Movimento (ICEM) organizei o Cinema pela Verdade. Durante a $29^{\circ}$ Reunião da ABA em Natal organizei junto com o Zoon Fotografias, a Exposição Multimídia de Antropologia Visual, que aconteceu no container, no pátio da UFRN

${ }^{10}$ Dando sequência essas atividades com temática África e pós-colonialismo organizei, em diferentes momentos, Mesa redondas, rodas de conversas e oficinas sobre "cinema e pesquisa audiovisual".

${ }^{11}$ É um projeto de extensão que integra pesquisa, ensino, com objetivo de aprimorar e discutir a respeito da necessidade de uma ação educativa através da imagem. A partir de uma perspectiva interdisciplinar, caracterizada pela interação de conceitos e de metodologias oriundos das várias áreas do conhecimento (Antropologia, Letras, Comunicação, História), pretende-se caminhar pelos espaços do Rio Grande do Norte em busca das histórias que precisam ser escutadas e abraçadas. Sabemos que quem conta sua história reconstrói sua memória, percebe também a dimensão do que realizou e reafirma a capacidade de decidir e participar da história de um lugar.

${ }^{12}$ Por este motivo o método escolhido é de estender o tempo de gravações e de encontros com o entrevistado, é uma maneira de permitir que a memória que está submersa venha a dar significado para o que é mais significativo para o grupo: a grande memória coletiva do grupo e de um lugar. Gravar algo que não é visível só se consegue na imersão, na troca de pertenças e saberes.

\section{REFERÊNCIAS}

ARMS, Roy. O cinema africano ao norte e ao sul do Saara in cinema no mundo: indústria, política e mercado: África. (org. Alessandra Meleiro) - São Paulo, escrituras Editoras, 2007 (coleção cinema no mundo).

APPADURAI, Arjun. Theory in anthropology: center and periphery. Comparative Studies in Society and History, v. 28, n. 1, 1986.

AUGÉ, Marc. Quem é o outro? Os outros e seus sentidos. O Outro próximo. In: O sentido dos outros. Rio de Janeiro: Vozes, p 11-76, 1999.

BAIRD, J. Comic voice: Community education through sequential art. St. Louis: Pop Culture Association - American Culture Association, 2010.

BAMBA, Mahomed. Jean rouch: cineasta africanista? Devires, v. 6, n. 1, p. 92-107, jan./jun. 2009. 
BOUGHEDIR, Ferid o cinema africano e a ideologia: tendências e evolução in cinema no mundo: indústria, política e mercado: África. (org. Alessandra Meleiro) - São Paulo, escrituras Editoras, 2007 (coleção cinema no mundo).

BARBOSA, Andréa; CUNHA, Edgar Teodoro da. Antropologia e Imagem. Rio de janeiro: Jorge Zahar Ed., 2006.

BHABHA, Homi. The location of culture. London, New York: Routledge, 1995.

BLACKMAN, A.; FAIREY., T. The Photovoice Manual A guide to designing and running participatory photography projects. Londres: Photovoice, 2007.

BOLTON, A.; POLE, C.; MIZEN, P. (2001). Picture this: researching child workers. Sociology, v. 35, n. 2, 501-518, 2001.

BRUN, Eliane. Olho da Rua, O: Uma Repórter Em Busca da Literatura da Vida Real. São Paulo, Martins Fontes, 2017.

CALDEIRA, Tereza. A política dos outros: o cotidiano dos moradores da periferia e o que pensam do poder e dos poderosos, São Paulo: Brasiliense, 1984.

CALVINO, Ítalo. As cidades invisiveis. 6. ed. São Paulo: Companhia das Letras, 1994.

CANCLINE, Nestor G. Culturas Hibridas. Estrategias para entrar y salir de la modernidade. México: Grijaldo, 1989.

CANEVACCI, Máximo. A Cidade Polifônica: Ensaio sobre a antropologia da comunicação urbana, São Paulo: Nobel, 1993.

CARDOSO, Ruth. (org.). A aventura antropológica: teoria e pesquisa. Rio de Janeiro: Paz e Terra, 1986.

CARDOSO DE OLIVEIRA, Roberto. Sobre o Pensamento Antropológico. Rio de Janeiro: Tempo Brasileiro/Cnpq, 1988.

. A Dupla interpretação em Antropologia. Anuário Antropológico 94. Brasília: Tempo Brasileiro, p. 9-20, 1995.

. A categoria de (des)ordem e a pós-modernidade da antropologia. In: Sobre o pensamento antropológico. 2. ed. Rio de Janeiro: Tempo Brasileiro, 1997.

.O trabalho do Antropólogo. Brasília Paralelo 15. São Paulo Editora da UNESP, 2000.

CASCUDO, Luís da Câmara. História da cidade do Natal. 2. ed. Rio de Janeiro: Civilização Brasileira, 1985.

CASTELLS, Manuel. A questão urbana, Rio de Janeiro: Paz e Terra, 1983.

CAIUBY Novaes, Sylvia. "Imagem, magia e imaginação: desafios ao texto antropológico", Mana, v. 14, n. 2, Rio de Janeiro Out. 2008.

CORADINI, Lisabete. Desvio na Praça, Monografia Curso de Ciências Sociais, UNISINOS, RS, 1990. 89 p.

. Praça $X V$ : espaço e sociabilidade. Florianópolis: Letras Contemporâneas/Fundação Franklin Cascaes, 1995, 157 p. (Série Dissertações).

. Memorias del futuro. Imágenes y discursos de la ciudad latinoamericana. Tesis de Doctorado. México: IIA/UNAM, 2000. 225 p.

. Imagem e cultura na Ciudad de México. In: VALENÇA, Márcio (org.).

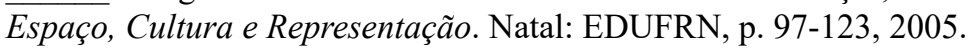

288 CORADINI, Lisabete; PAVAN, Maria Angela. (orgs.). Narrativas, Memórias e Itinerários. 1. ed. Campina Grande: EDUEPB, v. 1. 290 p. 2018.

. Dossiê: Antropologia e Investigação Audio Visual. In: Vivência: Revista de Antropologia, v. 1, p. 133, 2017.

. Mulheres das Rocas: imersão do documentário no espaço-tempo dos personagens do samba em Natal/RN. Vivência: Revista de Antropologia, v. 1, p. 133, 2017. 
. No mato das Mangabeiras: por uma etnografia da duração na construção do documentário. Vivência: Revista de Antropologia, v. 1, p. 181-192, 2016. . As mulheres das Rocas, o tempo dos personagens do samba em natal. $\overline{R e v i s t a}$ Eletrônica Visagem, v. 2, p. 181, 2016.

. Seu Pernambuco. Revista Eletrônica Visagem, v. 2, p. 249, 2016.

CORADINI, L. SOUZA, V. K. A. Os ciganos do Rio Grande do Norte: caminhos e trânsitos. Sociologia (Porto), v. 1, p. 205-229, 2014.

CORADINI, L.; FEREIRA, C. O Gesto do animador Moustapha Alassane e o cinema. Contemporânea (UFBA. Online), v. 11, p. 569, 2013.

CORADINI, L.; KNOX, W. Imagens e espelho: reflexões sobe o uso da fotografia no trabalho de campo em comunidades pesqueiras. Cadernos de Antropologia e Imagem (UERJ), v. 9, p. 117-136, 2009.

CORADINI, L.; PAVAN, M. A. Documentário, Memória e Narrativas: Métodos para uma etnografia da duração na realização de uma produção audiovisual. In: FERNÁNDEZ, PADILHA, Adrían; MALDONADO, Alberto Efendy; VELA, Norah S. Gamboa. (orgs.). Procesos Comunicacionales Educacion y Ciudadania en las luchas de los pueblos. 1. ed. Caracas: Cepap/ UNESR, p. 133-148, 2015.

CORADINI, L.; SAMAIN, E. De algumas estruturas que se conectam: uma entrevista com Etienne Samain. In: CORADINI, Lisabete; MILLER, Francisca. (orgs.). Imagens e Meio Ambiente: debates atuais. Natal: EDUFRN, 2011, v1, p 12-32., v 1, p 12 -32 1, p 12 -32.

CORADINI, L. Confissões Antropológicas. In: SCHWADE, E: VALE, Carlos Guilherme Octaviano. (orgs.). Processo Sociais, Cultura e Identidade. São Paulo: Annablume, v. 1, p. 289-322, 2010.

. O ensino de antropologia visual na graduação. In: FERRAZ, Ana Lúcia Camargo; MENDONÇA, João Martinho de; FERRAZ, Ana Lúcia Camargo. (orgs.). Antropologia visual: perspectivas de ensino e pesquisa. 1. ed. Brasilia: ABA, v. 1, p. 233-255, 2014.

. Cidades, imagens e desordem. In: ALMEIDA, Maria da Conceição; GALENO, Alex. (orgs.). Ensaios de Complexidade. 1. ed. Natal: EDUFRN, v. 1, p. 197-212, 2013.

. Marcas urbanas: modernidade esquecida. In: JÚNIOR, Aryovaldo de Castro Azevedo. (org.). Brasil: uma marca em construção. 1. ed. São Paulo: Parágrafo Comunicação, v. 1, p. 115-134, 2013.

. O audiovisual africano como revolução. In: PEIXOTO, Clarice; COPQUE, Barbara; CARVALHO, Cesar Augusto; SOUZA, Edney Clemente. (orgs.). Imagens e Narrativas. 1. ed. Rio de janeiro: UERJ, v. 1, p. 428-452, 2012.

. As cidades do futuro: imagens e antecipações urbanas. In: CORADINI, Lisabete; MILLER, Francisca. (orgs.). Imagens e Meio Ambiente: debates atuais. Natal: EDUFRN, v.1, p. 35-54, 2011.

. Quando fomos modernos. Revista Anthropológicas, v. 20, p. 219-242, 2009.

O de cima sobe e o debaixo desce na cidade do sol. Os Urbanitas (São Paulo), v. 5, p. 7, 2008.

. Representations and images of Latin America. In: FOSTE, David e Araujo, CORREA, Denise. (orgs.). Visual Communication: Urban Representations in Latin America. Porto Alegre: Editora PLUS, v. 1, p. 297-318, 2009.

. Ponta Negra: um bairro em transformação. In: VALENÇA, Marcio; BONATES, Mariana. (orgs.). Globalização e Marginalidade: O Rio Grande do Norte em foco. 1. ed. Natal: EDUFRN, p. 599-610, 2008. 
CORADINI, L. Imagem e Cultura na Cidade do México. In: VALENÇA, Márcio Moraes; BRAGA, Maria Helena; COSTA, Vaz da. (orgs.). Espaço, cultura e representação. 1. ed. Natal: UFRN, v. 1, p. 5-264, 2005.

CORADINI, L. Memórias do Futuro. In: ALMEIDA, Maria C.; KNOBB, Margarida e ALMEIDA, Angela. (orgs.). Polifônicas ideias. Por uma Ciência Aberta. 1. ed. Porto Alegre: Sulina, v. 1, p. 246-249, 2003.

DA MATTA, Roberto. O Ofício de Etnólogo, ou como ter "Anthropological Blues". In: NUNES, Edson de Oliveira (org.). A Aventura Sociológica: Objetividade, Paixão, Improviso e Método na Pesquisa Social. Rio de Janeiro: Zahar Editores, p. 23-35, 1978.

ECKERT, Cornélia; MONTE-MÓR, Patricia (orgs.). Imagem em Foco. Porto Alegre: Universitária UFRGS, 1999.

ECKERT, Cornélia; ROCHA, Ana. L. Carvalho. Etnografia de rua: estudo de antropologia urbana. Revista do Núcleo de Desenvolvimento da Criatividade da UNICAMP, v. 9, p. 101-127, 2003.

O antropólogo na figura do narrador. Revista Habitus, v. 1, n. 2, p. 395-420, 2004.

ECKERT, Cornélia; ROCHA, Ana. L. Carvalho. O tempo e a cidade. Porto Alegre, UFRGS, 2005.

FEATHERSTONE, Mike. Undoing Culture. Globalization, Postmodernism and Identity. London/Thousand Oaks/. New Delhi, SAGE,1995.

FELDMAN-BIANCO, Bela; LEITE, Miriam Moreira (orgs.). Desafios da Imagem: fotografia, iconografia e vídeo nas Ciências Sociais. Campinas: Papirus, 1998.

FONSECA, Claudia. Família, fofoca e honra. Porto Alegre: UFRGS, 2001.

GADAMER, Hans Georg. Verdad y Metodo. Fundamentos de uma hermenêutica filosófica. 3. ed. Salamanca: Sígueme, 1988.

GURAN, Milton. Fotografia para descobrir, fotografar para contar. In: Cadernos de Antropologia e Imagem, Rio de Janeiro: Editora UERJ, p. 153-165, 2000.

GRIMSHAW, Anna. The ethnographer's eye. Cambridge: Cambridge Univ. Press, 2001.

HARRISON, B. Seeing health and illness worlds - using visual methodologies in a sociology of health and illness: a methodological review. Sociology of Health \& Illness, v. 24, n. 6, p. 856-872, 2002.

HOLSTON, James. A cidade modernista: uma crítica de Brasília e sua utopia. São Paulo, Companhia das Letras, 1993.

KOURY, Mauro Guilherme Pinheiro (org.). Imagem \& ciências Sociais. João Pessoa: Universitária UFPB, 1998.

LEFEBVRE, Henri. O direito à cidade, São Paulo: Documentos, 1969.

LEITE, Rogerio Proença. Contra-usos e espaço público: notas sobre a construção social dos lugares na Manguetown, Rev. bras. Ci. Soc., SãoPaulo, v. 17, n. 49, p. 115-134, jun. 2002.

MACDOUGALL, David. De quem é essa história? Cadernos de Antropologia e Imagem, v. 5, n. 2. Rio de Janeiro: UERJ, 1997.

MAGNANI, José Guilherme C. Quando o campo é a cidade. In: MAGNANI, J. José Guilherme C. e TORRES, Lilian de Lucca (orgs.). Na metrópole: textos de Antropologia Urbana, São Paulo: EDUSP/FAPESP, p. 12-53, 1996.

MAGNANI, J.G. De perto e de dentro: notas para uma etnografia urbana. Revista Brasileira de Ciências Sociais, v. 17, n. 49, p. 11-29, 2002.

MALINOWSKI, Bronislaw. Argonautas do Pacifico Ocidental. São Paulo, Abril, v. XLIII, 1976. 
MARCUS, Georg. Identidades passadas, presentes e emergentes: requisitos para etnografias sobre a modernidade no final do século XX ao nível mundial. Revista de Antropologia, São Paulo, FFLCH/USP, v. 34, 1991.

MINER, Horace. Ritos corporais entre os Nacirema. A. K. Romney e P. L. Devore (eds.): You and Others - readings in Introductory Anthropology. Winthrop Publishers, Cambridge, p. 72-76, 1973 (Tradução: Selma Erlich).

OLIVEN, Ruben George. A Antropologia de Grupos Urbanos. 5 ed. Petrópolis: Vozes, 2002.

PAVAN, Maria Angela; CORADINI, Lisabete. Estratégias Metodológicas na construção de documentários: em campo com as mulheres das Rocas Natal/RN. In: Avanca - Cinema 2018, 2018, Avanca - Portugal. Avanca Cinema - Internacional Conference 2018. Avanca - Portugal: Edições Cine-Clube de Avanca, v. 2, p. 646-652, 2018.

PARK, Robert. A cidade: sugestões para a investigação do comportamento humano no meio urbano. In: VELHO, Otávio. (org.). O fenômeno urbano. Rio de Janeiro, Ed. Guanabara, p. 26-67,1987.

PEIRANO, Mariza. Uma antropologia no plural: três experiências contemporâneas. Brasília: EdUNB, 1992a.

. Os antropólogos e suas linhagens. Série Antropologia, n. 130. Brasília: Departamento de Antropologia da UNB, 1992.

. A favor da etnografia. Rio de Janeiro: Relume-Dumará, 1995.

. Onde está a antropologia? Mana, v. 3, n. 2. Rio de Janeiro, 1997.

. A alteridade em contexto a antropologia como ciência social no Brasil. Série Antropologia, n. 255. Brasília: Departamento de Antropologia da UNB, 1999.

PEREZ TAYLOR, Rafael. Entre la tradición y la modernidad. Antropología de la memoria colectiva, México: UNAM, 1996.

PERLONGHER, Nestor. O Negócio do Michê, prostituição viril em São Paulo. São Paulo: Brasiliense, 1987.

RABINOW, Paul. Antropologia da razão. Rio de Janeiro: Dumará, 1999.

REDFIELD, Robert. Civilização e Cultura de Folk. São Paulo: Martins Editora, 1949.

RIAL, Carmem S. "Contatos fotográficos: nativos, antropólogos, jornalistas e turistas. Diferentes linguagens fotográficas?" In: KOURI, Mauro. (org.). Imagens e Ciências Sociais. João Pessoa: Universitária UFPB, p. 203-224, 1998.

RIBEIRO, José da Silva, Jean Rouch: Filme Etnográfico e Antropologia Visual. n. 3, p. 6-5, 2007.

ROCHA, Ana Luisa. Antropologia das formas sensíveis: entre o visível e o invisível, a floração de símbolos? In: Horizontes Antropológicos, Porto Alegre, ano 5, n. 12, p. 59-68, 1999.

ROCHA, Ana Luiza Carvalho; ECKERT, Cornélia. Antropologia da e na cidade: interpretações sobre as formas da vida urbana. Porto Alegre: Marcavisual, 2013.

SAMAIN, Étienne. Quando a fotografia (já) fazia os antropólogos sonharem: o jornal La Lumière. Revista de Antropologia, v. 44, n. 2, São Paulo: USP, 2001. . (org.). O Fotográfico. São Paulo: Hucitec, 1998.

SILVA, M. A. Eduardo Coutinho e o cinema etnográfico para além da Antropologia. Cambiassú. São Luís: UFMA, p. 161-174, 2010.

SIMMEL, Georg. A Metrópole e a vida mental. In: VELHO, Otavio. (org.). $O$ fenômeno urbano. Rio de Janeiro: Zahar, 1967. 
VELHO, Gilberto. Observando o Familiar. In: NUNES, Edson de Oliveira (org.). A Aventura Sociológica: Objetividade, Paixão, Improviso e Método na Pesquisa Social. Rio de Janeiro: Zahar Editores, p. 36-46, 1978.

. (org.). O desafio da cidade. Rio de Janeiro: Campus, 1980.

. Individualismo e cultura: notas para uma antropologia da sociedade contemporânea. Rio de Janeiro: Zahar, 1981.

. Projeto e Metamorfose. Antropologia das sociedades complexas. Rio de Janeiro: Jorge Zahar Editor, 1994.

. Desvio e divergência: uma crítica da patologia social. 7. ed. Rio de Janeiro: Jorge Zahar Editor, 1999.

. Os mundos de Copacabana. In: VELHO, Gilberto. (org.). Antropologia urbana: cultura e sociedade no Brasil e em Portugal. Rio de Janeiro: Zahar, p. 11-23, 1999.

. (org). Antropologia Urbana: cultura e sociedade no Brasil e em Portugal. 2. ed. Rio de Janeiro: Zahar, 2002.

WANG, C.; BURRIS, M. A. Empowerment through Photo Novella: Portraits of Participation. Health Education Quarterly, v. 21, n. 2, p. 171-186, 1994.

WIRTH, Louis. O Urbanismo como Modo de Vida. In: VELHO, Otávio (org.). O fenômeno urbano. Rio de Janeiro: Zahar, 1987.

ZALUAR, Alba. A máquina e a revolta: as organizações populares e o significado da pobreza. São Paulo: Brasiliense, 1985.

ZALUAR, Alba; ALVITO, Marcos. (orgs.). Um século de favela. Rio de Janeiro: FGV, 1998. 